\title{
Variações sobre o documentário de Vincent Carelli - (Des)fazendo o novelo
}

\author{
Marcos Aurélio Felipe*
}

Resumo: $\mathrm{O}$ artigo analisa a escritura documental de Vincent Carelli no contexto da mídia indígena. O objetivo é investigar como o filme A festa da moça (1987), com os seus dispositivos de (trans)figuração e (re)invenção do mundo histórico, ecoa na obra de Vincent Carelli e dos cineastas indígenas vinculados ao Vídeo nas Aldeias (VNA), problematizando a percepção de si, a (re)encenação da tradição, o sistema de reutilização imagético, a (auto)referencialidade, os desvios narrativos, o lugar do Outro e a questão indígena no Brasil.

Palavras-chave: Vincent Carelli; Vídeo nas Aldeias; cineastas indígenas; documentário; povos originários.

Resumen: El artículo analiza la escritura documental de Vincent Carelli en el contexto del audiovisual indígena. El objetivo es investigar cómo la película A festa da moça (1987), con sus dispositivos de (trans)figuración y (re)invención del mundo histórico, resuena en la obra de Vincent Carelli y de los cineastas indígenas vinculados al Vídeo en las Aldeas (VNA), problematizando la percepción de sí mismos, la (re)puesta en escena de la tradición, el sistema de reutilización imagética, la (auto)referencialidad, los desvíos narrativos, el lugar del Otro y la cuestión indígena en Brasil.

Palabras clave: Vincent Carelli; Vídeo en las Aldeas (VNA); cineastas indígenas; documental; pueblos originarios.

Abstract: The text analyzes the documentary writing of Vincent Carelli in the context of the indigenous media. The objective is to investigate how the film A festa da moça (1987), with its devices of (trans)figuration and (re)invention of the historical world, resonate in the work of Vincent Carelli and the indigenous filmmakers linked to the Video in the Villages (VNA), problematizing the perception of self, the re-enactment of tradition, the system of imagery reuse, (self) referentiality, narrative deviations, the place of the Other and the indigenous question in Brazil.

Keywords: Vincent Carelli; Video in the Villages (VNA); indigenous filmmakers; documentary; indigenous people.

* Universidade Federal do Rio Grande do Norte - UFRN, Centro de Educação CE, Departamento de Práticas Educacionais e Currículo - DPEC. 59078-970, Natal, Brasil. E-mail: aurelio.felipe@uol.com.br

Este artigo é resultado do projeto de pesquisa de pós-doutorado: "Visões do mundo indígena:mediações fílmicas do mundo histórico dos povos originários no Brasil - produção e formação audiovisual do projeto Vídeo nas Aldeias (VNA)" - vinculado a Universidade Federal do Rio Grande do Norte (UFRN) e ao Programa de Pós-Graduação em Comunicação (PPGCom/UFPE), sob a supervisão da Professora Doutora Titular Angela Prysthon (UFPE).

Submissão do artigo: 19 de agosto de 2018. Notificação de aceitação: 24 de dezembro de 2018 .

Doc On-line, n. 25, março de 2019, www.doc.ubi.pt, pp. 6-46. 
Résumé : L'article analyse l'écriture documentaire de Vincent Carelli dans le contexte des médias autochtones. L'objectif est d'étudier comment le film A festa da moça (1987), avec ses dispositifs de (trans)figuration et de (ré)invention du monde historique, fait écho et renvoie au travail de Vincent Carelli ainsi qu'aux réalisateurs indigènes associés au Projet Vidéo dans les villages (VNA), problématisant la perception de soi, la reconstitution de la tradition, le système de réutilisation des images, le (soi)référentialité, les déviations narratives, la place de l'autre et la question indigène au Brésil.

Mots-clés : Vincent Carelli ; Vidéo dans les villages (VNA) ; cinéastes autochtones ; documentaire ; peuple d'origine.

Os Nambiquara tem conhecimentos toxicológicos. Fabricam curare para suas flechas a partir de uma infusão da película vermelha que reveste a raiz de certos strycnos, os quais deixam evaporar ao fogo até que a mistura adquira uma consistência pastosa; e empregam outros venenos vegetais que cada um transporta consigo na forma de pós guardados em tubos de pena ou de bambu, enrolados em fios de algodão ou de casca de árvore [...] Além desses venenos de caráter científico, os Nambiquara tem outros cuja natureza é misteriosa. Em tubos idênticos aos que contem os venenos verdadeiros, colhem partículas de resina expelidas por uma árvore do gênero Bombax, de tronco avolumado em sua parte média; acreditam que, projetando uma partícula num adversário, provocarão uma condição física como a da árvore: a vítima inchará e morrerá. Trate-se de venenos verdadeiros ou de substâncias mágicas, os Nambiquara os designam todos com o mesmo termo: nandé.

Claude Lévi-Strauss

(Tristes Trópicos, 1954)

O sujeito se constitui ou se reconhece a si mesmo nos objetos que produz, e se conhece objetivamente quando consegue se ver "de fora", como um "isso". Nosso jogo epistemológico se chama objetivação; o que não foi objetivado permanece irreal e abstrato. A forma do Outro é a coisa.

Eduardo Viveiros de Castro

(A inconstância da alma selvagem, 2002)

Vocês brancos estão fazendo tudo errado!

Indígena Enawenê-nawê

(Yaõkwa, 2009)

\section{Introdução}

Do Vídeo nas Aldeias (VNA) como programa de intervenção do Centro de Trabalho Indigenista (CTI), até final da década de 1990, a Organização Não Governamental (ONG), a partir do ano 2000, com os seus próprios projetos e atividades, o cineasta e indigenista franco-brasileiro Vincent Carelli já tem mais de três décadas trabalhando com cinema documentário e aproximadamente 30 filmes em seu curriculum (entre curtas, médias e longas- 
metragens) ${ }^{1}$. Produziu uma obra que vai além de Martírio (2016) e Corumbiara $(2009)^{2}$, talvez os seus dois filmes mais conhecidos do público que acompanha sua trajetória e o cinema indígena no Brasil. De A festa da moça (1987) até $A$ morada de Hakowo (2017) ${ }^{3}$, realizado em parceria com Wewito Piyãko, do povo Ashaninka (Acre-AC) ${ }^{4}$, desenvolveu vasto painel cinematográfico, antropológico e histórico dos povos originários no Brasil. Tomando como objeto as dimensões fílmicas, históricas e políticas de A festa da moça, que transbordam em seus outros filmes e nas cinematografias indígenas produzidas no âmbito do VNA, neste ensaio abordamos como a escritura documental de Vincent Carelli acontece em uma perspectiva de rede e se desdobra em um labirinto de múltiplas formas e reflexos.

Nesse trajeto, subordinamos a interpretação às etapas da análise (descrição e interpretação), com os filmes como ponto de partida e de chegada. Analisamo-los como objetos em si e, ao mesmo tempo, em diálogo com o seu entorno (histórico, étnico e filmográfico). Pensamos o cinema como instância problematizadora e não como pretexto para aplicação teórica (Aumont, 1995; Penafria, 2009; Vanoye; Goliot-Lété, 1994) ${ }^{5}$. Como sempre, divisamos não o mundo indígena em imagens, mas um mundo imagético, mediatizado, fílmico, a partir de um processo de documentação e (re)invenção de formas, constituído e constitutivo, com o Outro, permanentemente, em perspectiva e na cena documentária, em toda a sua complexidade e singularidade, como delineado na acepção de Marcius Freire (2011: 75): "O Outro, o não ocidental, o diferente, seu corpo, paramentado ou desnudo, sua terra, seu habitat, suas crenças, seus atos sexuais e gastronômicos". Como os filmes não são casos isolados, parti-

1. Sem contabilizar os dez episódios da série de TV Índios no Brasil (2000) e os quatro do Programa de Índio (1995/96). Essas séries foram produzidas, respectivamente, em parceria com a TV Escola e a TV Universitária da Universidade Federal do Mato Grosso (UFMT).

2. Corumbiara e Martírio integram uma tetralogia que se completará com Adeus, Capitão (Cesar et al, 2017: 254) e outro documentário sobre o povo Kayapó Xikrin, com o qual Vincent conviveu, aos 16 anos, quando ainda eram isolados (CINUSP Paulo Emílio, 2017). O capitão do terceiro filme é o líder dos Gavião Parkatêjê: Topramre Krohokrenhum Jõpaipaire.

3. A morada de Hakowo é o episódio 12 da série de TV Nokun Txai, Nossos Txais (2017), composta por 13 episódios sobre os povos indígenas do Acre e produzida pela Saci Filmes com direção geral de Sérgio Carvalho (Rede Amazônica/Acre, 2016).

4. Os Ashaninka, que integram a família linguística Aruak, habitam o Acre e o Peru e, respectivamente, compreendem uma população de 1.645 (Siasi/Sesai, 2014) e 94.477 (INEI, 2007) indivíduos. A história do contato foi marcada, desde o século XVI, pelas missões religiosas e, no Século XX, pela exploração da borracha (Povos Indígenas do Brasil/Instituto Sócio-ambientalISA, 2018).

5. Em um estudo mais específico com enfoque educativo, a partir da obra do documentarista brasileiro Aloysio Raulino, identificamos e analisamos de forma mais abrangente os processos, as categorias e as etapas que envolvem a análise fílmica (Felipe, 2018a). 
mos de $A$ festa da moça, cujos traços, processos e dispositivos, ao ecoarem nas filmografias de Vincent e dos cineastas e coletivos indígenas, são analisados a partir de um sistema de ressonâncias de imagens que se invadem, transformamse e, em conjunto, confrontam o mundo histórico, similar ao que vivemos e em constante mutação dialética com as circunstâncias do real (Nichols, 2005: 2627): "um mundo que já ocupamos e compartilhamos", "a matéria de que é feita a realidade social", o que "foi, é e o que poderá vir a ser".

\section{Do contexto ao objeto}

No intervalo entre a crítica pós-colonial e os estudos de cinema, que, para Angela Prysthon (2016: 82), abre um "tráfego de influências mútuas", o lugar reservado aos filmes frente às demandas vinculadas ao subalterno, ao periférico, ao marginal, historicamente, desemboca no Terceiro Cinema ${ }^{6}$. Sua dimensão política, de Glauber Rocha a Jorge Sanjinés, é devedora da matriz histórica que, no pós Segunda Guerra, passa a ser conhecida como Terceiro Mundo $^{7}$, com todas as expectativas quanto aos seus aspectos libertários, idealistas e de não vinculação às potências imperialistas - capitalistas ou socialistas - do século 20. O Terceiro Cinema acabou promovendo uma "interpretação subalterna" e a "negação desse cosmopolitismo tradicional onde existe um centro metropolitano definindo o que os povos subalternos devem fazer" (Prysthon, 2006: 9-10). Com a crise da retórica terceiro-mundista nos anos 1980, ocorre a passagem para a estética periférica das décadas seguintes, que se funda nos 'princípios de 'recuperação', de 'reciclagem' e de 'retomada' da tradição, da história e de um certo exotismo" e numa espécie de "'ressurgência da periferia' ou 'reencenação da subalternidade"' (Prysthon, 2006: 10-11). Entretanto, apesar de articular o arcabouço político-social do Cinema Novo ou do Nuevo Cine Latinoamericano, os cineastas periféricos apenas, artificialmente, produzem uma crítica às estruturas de poder, desenhando-se em um certo "cosmo-

6. Terminologia que, ao aparecer pela primeira em Hacia um Tercer Cine, escrito por Fernando Solanas e Octávio Getino, em 1969, refere-se aos cinemas novos latino-americanos da década de 1960 e as cinematografias insurgentes dos países não alinhados ao Primeiro e ao Segundo mundos (Prysthon, 2016).

7. "O Terceiro Mundo é composto por nações e 'minorias' colonizadas, neocolonizadas ou descolonizadas cujas desvantagens estruturais foram formadas pelo processo colonial e por uma divisão internacional do trabalho injusto. [...] Como coalização política, o Terceiro Mundo se une em torno do entusiasmo gerado pelas lutas anticoloniais no Vietnã e na Argélia e surge concretamente na Conferência de Bandung de países asiáticos e africanos 'não alinhados' em 1955. O termo foi cunhado pelo demógrafo francês Alfred Sauvy nos anos 50 como analogia do 'terceiro estado' da França revolucionária" (Shohat; Stam, 2006: 55). 
politismo" que dá ares global ao local e em uma práxis publicitária na qual a anulação do Outro é notória.

Essas tendências, aparentemente, apresentam molduras que, de forma apressada, poderiam ser usadas para situarmos o Vídeo nas Aldeias. Não como uma das suas vertentes ou reflexos contemporâneos, é claro, mas como se, ao bordear as mesmas margens, carregasse ethos igual ou semelhante. Entretanto, como projeto do CTI ou ONG, o VNA mais se aproxima das bordas do que se filia ao arcabouço histórico-político-estético do Terceiro Cinema, do cinema periférico ou de outra tendência similar, pois apenas negar um centro produtor que fala pelo Outro e dar voz a camadas subalternas do mundo contemporâneo não são condições suficientes para vincularmos a poética de Vincent Carelli e dos coletivos de cineastas indígenas as escrituras dos diretores do Cinema Novo, do Nuevo Cine Latinoamericano e/ou de um certo cinema brasileiro dos anos 1990/2000 - que subiram a favela, adentraram o sertão e conversaram com moradores de ruas sem transformarem a condição de receptáculo dos seus sujeitos.

Na verdade, as cinematografias indígenas apontam para outras problemáticas, a partir do olhar participativo dos realizadores não indígenas e do olhar de dentro dos cineastas nativos, a partir do qual, nas palavras de Lévi-Strauss (Araújo, 2011: 156), "Temos constantemente a sensação de sermos autorizados a ver a vida indígena por dentro" ${ }^{8}$. São propostas que vão além das tendências globalizantes, como analisam Salazar e Córdova (2008) com base no conceito de "embedded aesthetics" de Faye Ginsburg ${ }^{9}$, pois desenvolvemse no interior das questões fundamentais dos povos originários, com foco nas demandas comunitárias, nos processos de intervenção político-cultural e de acordo com as suas próprias lógicas locais, o que impede dos filmes ser transforados em documentários "sobre" pelo enraizamento das suas abordagens, forma-conteúdo. São aspectos que encerram a própria definição de mídia indígena, cuja aplicação deve compreender os processos e produtos dos realizadores indígenas e - também - dos não indígenas, ainda que nos coloque diante, no caso brasileiro, do paradoxo pós-colonial do cinema indígena feito por homens-brancos-europeus-estrangeiros pertencentes a matrizes colonizadoras de outrora. Ao ampliar o raio conceitual, o enraizamento dos cineastas no fulcro dessas questões fundamentais é o que distingue a poética de um Vincent Carelli (ou de um Andrea Tonacci) dos registros de certas etnografias cinematográficas que, sem conseguirem se desvencilhar do olhar colonizador,

8. Claude Lévi-Strauss chegou a ver alguns filmes do vNA.

9. Embedded aesthetics: "se traduce como estéticas incrustadas o enraizadas, que denotan el modo de producción de las obras, determinando los procesos de producción así como los productos mismos" (Córdova, 2011, p. 83). 
posicionam-se desde fora com imagens "sobre" e não "com" ou "por meio" do Outro.

Em nenhum momento, portanto, o VNA preocupa-se em ser um contraponto ao cinema hegemônico-industrial-hollywoodiano, nos termos de Shohat e Stam (2006), ou com qualquer filiação programada às formas e estéticas modernas. Sem contar que, diferentemente do Terceiro Cinema, o cinema indígena está vinculado ao contexto geográfico, político e étnico do Quarto Mundo: locus dos sujeitos que habitam o campo e o antecampo do Vídeo nas Aldeias - com os seus próprios princípios históricos, modos de ser e de viver. Existindo no interior das estruturas nacionais, coabitando e se desenvolvendo em interdependência com o entorno político-econômico, o Quarto Mundo aparece como um locus geo-político-étnico particular (Shohat; Stam, 2005). De suas questões, configurando-se como poética de los medios imperfectos (Salazar, 2004; Salazar e Códova, 2008: 50 - tradução nossa), desenvolve-se uma mídia indígena em busca de "novas formas de linguagens, de linguagens nãorelacionadas com a perfeição técnica ou com as regras e modos convencionais de representação e narrativização. Funda-se nas necessidades de seus usuários em um ambiente comunitário, mas com o olhar voltado para o contexto intercomunitário e transnacional". O que permite, em conjunto com o enraizamento das suas estéticas e com a pressão das problemáticas locais, a decolonialidade (Mignolo, 2017; Quijano, 2005) das poéticas dos realizadores indígenas, mais do que dos cineastas do Terceiro Cinema ${ }^{10}$ e do Cinema Periférico - próximos do que chamamos "observadores externos" e com as fronteiras bem delimitadas entre produtores e espectadores.

Nesse território, que passou a apontar para outras formas constitutivas de um quarto cinema, que o conceito de mídia indígena abrange e encerra, o documentário de Vincent Carelli e dos cineastas indígenas do VNA, encontra o seu locus cinematográfico. Principalmente, porque aponta para um processo de autogestão, quando a câmera é posicionada no ombro de quem pertence ao campo e ao antecampo da imagem (Colombres, 1985), bem como pelo espaço aberto para a auto-mise em scène e demandas do Outro mesmo quando o cineastas não pertencem ao locus dos povos originários. No centro dessas questões, o movimento para que os espelhos passem a ser redirecionados para

10. Desejo de filiação estético ou de autorreflexividade, no sentido de Francis Vanoye e Anne Goliot-Lètè (1994: 23), quando colocam que todo filme se situa na "história das formas fílmicas [...] e inscrevem-se em correntes, em tendências e até em 'escolas' estéticas, ou nelas se inspiram a posteriori" - o que não caracteriza o VNA, mas ronda o Terceiro Cinema. "Esteticamente, o movimento se inspirou em correntes tão diversas quanto a montagem soviética, o teatro épico de Brecht, o neo-realismo italiano e até mesmo o documentário social de Grierson" (Shohat; Stam, 2006: 46). 
si e não mais regulados por um olhar externo, sendo a participação do Outro, em todas as etapas da produção audiovisual e, inclusive, teórica, tornou-se o fim a ser permanentemente buscado (Stam; Shohat, 2005: 413). Com o filme etnográfico e a mídia indígena, que colocam o Outro em cena, conceitos como autorrepresentação, indistinção entre produtores-espectadores e autoprodução coletiva são o que, de fato, caracteriza o cinema indígena. Portanto, o Vídeo nas Aldeias não se filia a um certo world cinema, que embala e transforma o subalterno em produto global, nem pode ser visto como uma "variante autorizada" (Prysthon, 2014: 14) - indutora de uma rebelião das imagens: consentida, controlada e comercializada pelo mainstream.

Rompendo essas margens, o cinema indígena, realizado "sobre"-“com""para"-e-"pelos" povos originários, propõe outro movimento diferente dos observadores externos que não adentram o campo - fílmico, histórico, geopolítico. Juan Francisco Salazar (2004, p. 82 - tradução nossa) lembra que, enquanto o Nuevo Cine Latinoamericano e o documentário social dos anos 1970 buscavam sempre falar pelo e "retificar" a imagem tradicional do Outro (o oprimido, o trabalhador, o camponês, o "índio"), sem a sua participação na definição dos processos e dos produtos, "os cineastas indígenas falam por si" de forma "radicalmente coletiva" - "com os participantes sendo chamados para colaborar, cooperar e co-produzir os seus próprios filmes". Nesse sentido, do filme etnográfico a mídia indígena, o campo apresentado por essas formas da antropologia fílmica (France, 2000), da antropologia da mídia (Salazar, 2004) ou da comunicação intermundos (Oliveira, 2018) ${ }^{11}$, é o que mais próximo apresenta um enquadramento para o cinema de Vincent Carelli. Entretanto, não deixamos de salientar, na esteira de Robert Stam (2008), que muitos dos limites do filme etnográfico, invariavelmente, revelam-se em procedimentos narrativos convencionais, como o da voice "científica" over e da reconstituição de práticas culturais há muito desaparecidas - sem a circularidade de outras vozes e quase sempre presos a reificação cultural. Nem de ressalvar, quando os cineastas etnográficos tentam "despir-se dos vestígios das atitudes coloniais" (Stam, 2008: 446), outros limites que aparecem como supostos avanços que não passam de atitudes apologéticas (Shohat; Stam, 2005): produção compartilhada e participativa, antropologia dialógica e distância reflexiva.

11. As aproximações e distanciamentos da mídia indígena com o campo de estudos cinema e antropologia geram um debate sem fim. Salazar (2004) chama atenção que para Bill Nichols é a mídia indígena quem melhor apresentará respostas para os limites da antropologia acadêmica, enquanto para Ruby, os povos originários não produzem etnografias, pois os filmes são produzidos sobre e consumidas na própria comunidade e não sobre um "Outro". 
São estratégias que, nas reflexões de Adolfo Colombres (1985) sobre Jean Rouch e Jorge Preloran, podem se transformar em moeda de duas faces a depender da política da imagem que move a câmera, pois, ao dizer sempre ao Outro o como e o que precisa ser feito, o ato de querer dar-lhe uma "voz", muitas vezes, o suprime (Salazar, 2004). Se esses traços estão presentes no documentário de Vincent, em nenhum momento, a sua escritura se reduz a cacoetes estéticos-antropológicos-narrativos como ocorre com a práxis de certos filmes etnográficos - como veremos adiante. Mas, com fortes doses críticas a colonialidade, constitui-se como contranarrativa pós-colonial equidistante entre o cinema etnográfico e a mídia indígena (que fala de dentro e de volta para a sociedade nacional). Se o conceito indigenous media, na terminologia americana, torna-se mais elástico com Faye Ginsburg (2011: 173), que, ao analisar a A arca dos Zo'é (1993) e Eu já fui seu irmão (1993), situa-o "entre a 'mídia indígena' feita por e para comunidades nativas e os filmes etnográficos", a questão é saber até onde um filme "para" e não "por meio" do Outro o transforma em sujeito das imagens.

Mas qual a real efetividade de um cinema indígena, quando, numa acepção coletiva da produção audiovisual, propõe que seja o Outro a responder por todo o processo de autogestão, sem qualquer mediação que não seja a do seu próprio mundo (histórico, cosmológico e político)? Em uma perspectiva histórica, respostas podem ser encontradas no fato americano, com Sol Worth e John Adair que, em 1966, trabalharam com os Navajo, de Pine Springs, no Arizona (EUA), o que os tornam, na antropologia visual, precursores da mídia indígena (Gonçalves, 2016) ${ }^{12}$. Analisando o fato latino-americano, do México, Bolívia, Colômbia, Chile, ao Brasil, Amalia Córdova (2011: 82-83) observa um "corpus bastante heterogêneo", "geograficamente disperso" e vinculado a "processos sociais e pressões locais", além de uma produção entre a visibilidade e a luta política, o documento e a atualidade, a educação cultural e o fortalecimento da identidade comunitária. Em parte significativa das experiências na América Latina, Córdova (2011: 83) lembra os filmes incorporam "valores, protocolos y metodologías de cada comunidad o pueblo indígena". Como acontecimento que pode ser identificado na linha do tempo, o Consejo latinoamericano de cine y video de los pueblos indígenas (CLACPI), criado, em 1985, no México, foi um marco da mídia indígena para a região, buscando

12. "Participaram do projeto: Sol Worth, John Aldair e Richard Chalfen (orientando de Worth). As preliminares do projeto começa em março de 1966, quando Adair e Worth viajam a Pine Springs com o intuito de organizar o projeto com os Navajo e saber se estariam interessados em participar. Durante junho e julho, oito horas por dia e cinco dias por semana, coordenam um workshop com objetivo de viabilizar que os próprios Navajo produzam seus filmes de modo que tenham controle sobre todas as etapas do processo" (Gonçalves, 2016: 659). 
autonomia e autogestão, promovendo e difundindo festivais por todo o continente (Salazar, 2004).

Pensando em termos de Brasil, as experiências remontam a década de 1970, com o cineasta ítalo-brasileiro Andrea Tonacci e os Canela Apanyekrá ${ }^{13}$, da Aldeia Porquinhos, no município de Barra do Corda, MaranhãoMA (Brasil). O objetivo era gravar, exibir e discutir com os indígenas as suas próprias gravações. O resultado foi o documentário Conversas no Maranhão (1983), no qual, diante de um contato ainda inicial dos Canela com o cinema, o projeto não foi adiante como previsto e Tonacci optou em "ser dirigido" pela comunidade que lhe dizia o que devia ser filmado (Araújo, 2015). Ainda nesse período, com o intuito de que produzissem as suas próprias imagens, Tonacci acompanhou as expedições da Funai junto aos Arara ${ }^{14}$ recém contatados (Caixeta de Queiroz, 2008) - experiência que resultou na série Os Arara (1980-1982) que teve alguns episódios exibidos na TV Bandeirantes ${ }^{15}$. Um pouco depois, entre 1985 e 1987, em um trabalho pioneiro junto aos Kayapó, o projeto Mekanon Opoi D'joi ("Ele que cria imagens") ${ }^{16}$ já trabalhava com o vídeo como documentação e comunicação intercultural, práxis política e avaliação da própria imagem pelos indígenas, além de ferramenta utilizada pelos Kayapó para realizarem os seus próprios registros (Frota, 2018), ou seja, as mesmas dimensões que viriam a ser desenvolvidas pelo VNA ${ }^{17}$.

Nesse contexto, como o VNA se constituiu? De projeto do CTI a ONG (ou escola de cinema), o vNA surge em 1986 e tem sua origem no projeto Interpovos - "de comunicação intertribal" por meio do audiovisual, que, nos

13. Os Canela Apanyekrá, que integram a família linguística Jê, habitam o Maranhão, compreendem uma população de 1.076 indivíduos (Siasi/Sesai, 2012). A história do contato está marcada pelas incursões de forças militares, no Século XVII; e pela presença do Serviço de Proteção ao Índio-SPI, a partir de 1938 (Povos Indígenas do Brasil / Instituto Sócio-ambiental-ISA, 2018).

14. Os Arara integram a família linguística Karib, habitam territórios do Pará, compreendem uma população de 377 indivíduos (Siasi/Sesai, 2014) e se autodenominam Ukaragma. A história do contato é marcada pela Transamazônica, na década de 1970 (Povos Indígenas do Brasil/Instituto Socioambiental-ISA, 2018).

15. César Guimarães (2012: 56), a partir dos fragmentos não editados e que não constam na montagem final, analisou esses passos seminais de Tonacci no campo das imagens com os Arara e identifica uma "mise en scène que destoa radicalmente das iconografias dominantes e oficiais - patrocinadas pelos órgãos de Estado - sobre o contato entre índios e brancos".

16. Coordenado pelos antropólogos-videomakers Mônica Frota, Renato Pereira e Luiz Henrique Rios, que resultou no filme Taking aim (1993, de Mônica Frota) premiado em diversos festivais internacionais.

17. Além das experiências históricas da mídia indígena mencionadas, sobre as experiências canadenses e australianas e de Terence Turner com os Kayapó, a partir de 1988, ler a tese de Araújo (2015: 75-110). 
anos 1970, foi proposto ao CTI por Andrea Tonacci (Carelli, 2011). Como o vídeo estava no início, o projeto não obteve êxito e só depois foi retomado como o conhecemos em sua primeira fase: como prática intercultural por meio das imagens - caracterização fundamental, pois destoa de uma mera práxis de registro a partir do cinema como documento. Em 2011, no livro comemorativo dos 25 anos do VNA, Vincent Carelli comenta que, de Norte ao Sul, já havia trabalhado com 37 povos, realizado 127 oficinas e produzido 87 filmes. Apesar desses dados já terem quase uma década, os números demonstram a espessura do trabalho, o que sinaliza para um arquivo documental sem precedentes. Em 2017, em uma entrevista à revista Zum, do Instituto Moreira Salles (IMS), esses dados são ampliados e sabemos que o vNA comportava um acervo de 8 mil horas sobre os povos originários, com registros de mais de 50 comunidades - dos quais uma parte significativa foi realizada pelos próprios cineastas e coletivos indígenas.

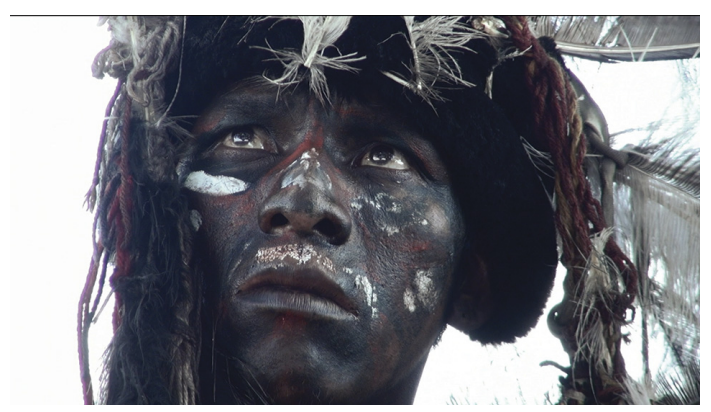

Figura 1. Martírio (2016) I C VNA

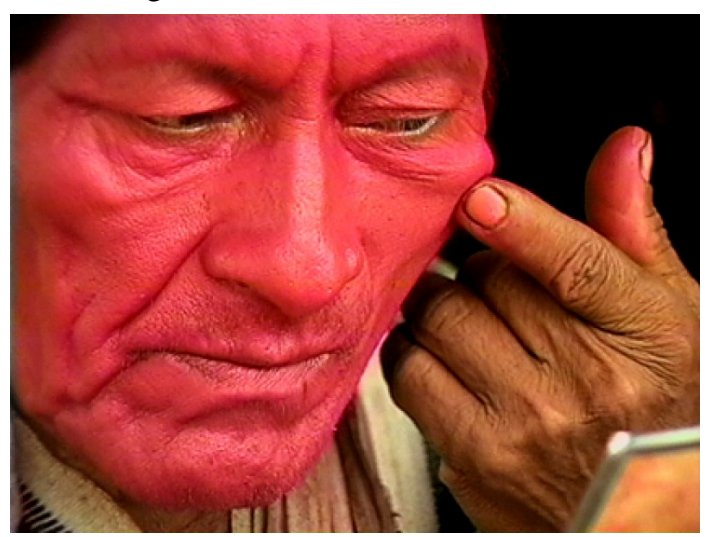

Figura 2. Shomtosi (2001) I C VNA 
Assim, constituiu-se como a principal memória audiovisual da história e da cultural indígena no país: em horizontalidade, pela dimensão quantitativa e geográfica que abrange; e, em verticalidade, pelo alcance qualitativo que se depreende, decorrente da importância dos registros e da abertura para o Outro também produzir as suas próprias imagens - a outra face do projeto e depois ONG e a mais fundamental da passagem da representação a autorrepresentação no campo da simagens. Independentemente de o VN ser ou não pioneiro, o trabalho desenvolvido por Vincent se tornou mais denso e longevo se comparado as outras experiências, espalhando-se por formatos e suportes diversos (cinema, vídeo, televisão) e ampliando o seu raio de ação pelo território brasileiro - dos Ashaninka do Rio Amônia, no Acre (AC), aos Guarani Mbya, das várias aldeias do Rio Grande do Sul (RS). Para nos situarmos em relação a essa expansão, como vemos em Antropofagia Visual (1995), o povo Enawenênawê, em meados dos anos 1990, era apenas a décima comunidade visitada pelo projeto apenas uma década após ter começado. Em um artigo publicado na revista Horizontes Antropológicos, nesse mesmo ano, sabemos que o CTI já havia implantado centros de produção audiovisual em 12 aldeias, além de apoiar o Kayapó Video Project (Gallois; Carelli, 1995: 62), com a edição de $O$ arquivo de vídeo Kayapó (1990-1991) e o trabalho de arquivamento do material bruto filmado pelos/com os indígenas (Araújo, 2015) ${ }^{18}$.

Em um projeto de cinema e formação, diretamente, interligado ao Outro, é possível de fato vincular o VNA à perspectiva roucheana de "antropologia partilhada"? Perspectiva que busca abolir as fronteiras entre sujeito-objeto e efetivar a passagem da descrição à participação do Outro na coprodução e coautoria do fazer documental (Freire; Lourdou, 2009). Nesse sentido, o que se observa é a simbiose dos cineastas não indígenas com os povos originários (Carelli, Gallois, Valadão, Corrêa), o entrelaçamento dos realizadores nativos com a sua própria comunidade (Zezinho Yube, Ariel Ortega, Divino Tserewahú) e parcerias longevas e verticais entre cineastas indígenas e não indígenas (Desterro Guarani, 2011; A morada de Hakowo). Além de toda a produção dos Coletivos que, mesmo quando o autoral desponta, quase sempre tem as demais funções assumidas por outros membros da comunidade. Entretanto, quais são os seus limites no âmbito do Vídeo nas Aldeias? Essa é mais uma problemática a ser analisada tendo em vista "a relação [entre os sujeitos envolvidos no fazer documentário] e seus desdobramentos: presença, reciprocidade e encontro" (Freire, 2011: 64). Porém, a partir de um trabalho analítico que considere os múltiplos contextos (histórico, étnico e cinematográfico) de um filme, resta

18. O Kayapó Video Project era coordenado pelo antropólogo Terence Turner. 
saber até que ponto as representações do cinema indígena superam as abordagens convencionais e apresentam outras visualidades.

Principalmente, porque, na acepção de Raquel Schefer (2016: 32), ao analisar outras latitudes cinematográficas, a categoria "rotação do olhar" aponta para dois sentidos fundamentais do lugar do Outro na imagem: "do sujeito de representação sobre o seu mundo e sobre si mesmo; [e] do observado sobre o observador" - quando, em uma perspectiva relacional, desloca os sujeitos de representação e de conhecimento e, retroativamente, restitui as condições perceptivas e cognitivas do sujeito colonizado para o entendimento multitemporal da história e das narrativas com consequências para a memória e o período colonial. Nesse sentido, Schefer (2016: 38-39) coloca que a rotação do olhar consolida "um olhar invertido, que desordena as categorias estabelecidas, nomeadamente as hierarquias da representação e das imagens, através de uma an-imagem, uma imagem oposta, contrária, em rotação". Nesse sentido, partimos do pressuposto que o cinema de Vincent Carelli não apenas está na base das escrituras dos cineastas e dos coletivos indígenas do VNA, que o ecoam e o refletem em permanência, mas no centro de uma poética que abre espaço para o Outro apresentar o seu ponto de vista, confrontar o registro em processo e colocar suas demandas. Isso é possível perceber a partir de uma ética documental que supera o "enquadramento institucional" para "filmar a singularidade do encontro com o outro" e colocar em crise "o modo de aproximação do invasor", se tomarmos de empréstimo as conclusões de Clarisse Alvarenga (2017: 38) sobre um espectro mais amplo do que o VNA. Assim, este estudo sobre A festa da moça pretende lançar luz sobre essas problemáticas que, em conjunto com outras, se desenharão no percurso, mas se o ponto de partida é a obra de Vincent, não é o nosso intuito estabelecer aqui as fases e/ou os modos da história do documentário (Nichols, 2005) ${ }^{19}$. E, sim, analisar como a tapeçaria da sua poética já estava sendo gestada no primeiro filme.

\section{Múltiplos reflexos}

A festa da moça é o primeiro documentário de Vincent Carelli e aborda as tradições dos Nambikwara ${ }^{20}$ - um ritual de iniciação feminina, os encontros

19. Para Bill Nichols (2005: 135),’Cada documentário tem sua voz distinta [...] No cinema, as vozes individuais prestam-se a uma teoria do autor, ao passo que as vozes compartilhadas, a uma teoria do gênero. $\mathrm{O}$ estudo dos gêneros leva em consideração os traços característicos dos vários grupos de cineastas e filmes [...] [Na história do cinema documental], podemos identificar seis modos de representação que funcionam como subgêneros do gênero documentário propriamente dito: poético, expositivo, participativo, observativo, reflexivo e performático".

20. Os Nambikwara ("orelha furada"), que integram a família linguística Nambikwara e habitam o Mato Grosso-MT e Rondônia-RO, compreendem uma população de 2.332 indivíduos 
dos diversos subgrupos, as rodas de conversas políticas e a catarse em função da presença da câmera no contexto das suas manifestações culturais. Não é a primeira obra da ONG Vídeo nas Aldeias e, sim, o primeiro filme finalizado pelo VNA como programa de intervenção do CTI. Do início ao fim das suas sequências, encontramos as dimensões formais e temáticas, políticas e etnográficas, ou seja, os traços, processos e dispositivos documentários que viriam a ser trabalhados, condensados e aprofundados pelo próprio Vincent e pelos cineastas indígenas formados nas oficinas audiovisual do VNA após a experiência da Oficina Multiétnica no Xingu, em 1997. Como exemplo, temos a incorporação e, ao mesmo tempo, o distanciamento das comunidades indígenas em relação ao mundo dos brancos, as visões sobre o Outro e a visão do Outro sobre o que está fora do seu mundo, o lugar da imagem nos processos de percepção identitária e de construção dos próprios documentários, o metafilme, a obra em processo e o documentário como making-off do próprio documentário. Além disso, os temas e as problemáticas recorrentes, como a vida na aldeia, a retomada das manifestações culturais (festas, rituais, jogos) e, sobretudo, a questão indígena.

Em A festa da moça, o narrador em off (distante do espaço fílmico e histórico retratado) conduz a narrativa e nos guia sobre o que se passa diante da câmera, sem identidade com a realidade objeto do relato, condensado, por sua vez, na perspectiva da transmissão de informação e não de pertencimento. Temos o narrador com a "voz do saber", como escreveria Bernardet (2003: 16-17): "voz de estúdio, sua prosódia é regular e homogênea, não há ruídos ambientes, suas frases obedecem à gramática e enquadram-se na norma culta [...] de um saber generalizante, que não encontra sua origem na experiência". O distanciamento ocorre justamente por ele não ser parte do mundo narrado, ao contrário do narrador em off de Martírio e de Corumbiara, assumido pelo próprio Vincent e feito de forma livre e longe dos cacoetes de locução radiofônica. Em A festa da moça, por consequência, o narrador promove também o nosso distanciamento, resvala no artificialismo da mesma forma que as imagens do prólogo, que interrompem o fluxo temporal que poderia ter um corpo sequencial e uma temporalidade. Já os Nambikwara, que se olham, veem-se e colocam em crise a sua performance no ritual de iniciação feminina, a partir de um monitor de TV implantado no centro de uma das aldeias pela equipe, dão mais concretude ao que vemos, pois veem-se, criticam suas próprias imagens e a refazem ao refazerem-se por mais de uma vez.

(Siasi/Sesai, 2014). Autodenominam-se Anunsu. A história do contato é marcada pela chegada da Comissão Rondon, em 1907 (Povos Indígenas do Brasil / Instituto Socioambiental-ISA, 2018). 
Em relação às imagens, entretanto, a identificação constitui recepções distintas.

Assentado no jogo de espelhos (como analisa o próprio Vincent no início de Corumbiara), com a fruição dos indígenas Nambikwara diante do seu próprio retrato refletido, A festa da moça provoca uma (re)estruturação da percepção daqueles sujeitos, que, ao analisarem seus reflexos realizados por outro, deixam de ser meros objetos de uma câmera externa ao seu mundo histórico, cultural, social. O narrador em off já havia nos informado que estávamos diante de um vídeo sobre o encontro dos Nambikwara com a sua própria imagem, como se se olhassem no espelho e divisassem personagens do seu próprio mundo. Portanto, esse filme é mais do que uma etnografia no sentido de padrões imagéticos preocupados tão somente com a descrição do Outro. Ao trabalhar com a imagem como catalisadora e não reflexo de eventos, que são mediatizados e não realidades de per si, a câmera de Vincent Carelli mobiliza outras realidades e provoca desvios narrativos para atender à evolução do mundo histórico diante das suas lentes. Referimo-nos aqui, por exemplo, às (re)encenações ${ }^{21}$ em cadeia do mesmo ritual, que se desenvolvem de forma contínua - objetivando ou parodiando a tradição.

Paradoxalmente, o filme não dá às imagens um caráter instrumental, cuja função seja descrever o Outro (Freire, 2011), o que o didatismo do narrador em off sugeriria em termos de uma imagem acessória - meramente, ilustrativa, ancilar. Ao contrário, A festa da moça constitui-se como um campo de transformação na/a partir da/com a própria imagem, dela se alimentando, com os registros dos sujeitos que se veem e, em uma oticidade em labirinto, refazem-se a partir das percepções sobre si. Esse estado de coisas no entorno da imagem, com o monitor de TV no centro da aldeia em um contexto de recepção organizada, desencadeia novas formas de colocar em cena o ritual de iniciação feminina - ou seja, da passagem de menina à moça depois de um período de reclusão. Portanto, evidencia-se uma nova performance da tradição, após o primeiro visionamento seguido da (re)encenação que, ao contrário dos procedimentos de reconstituição, na distinção feita por Alvarenga (2017: 84), cria espaços de espectatorialidade e subjetivação do próprio filme ou de outras imagens condensadas na materialidade narrativa.

21. Adotamos o entendimento de Amaranta Cesar (2012: 84) sobre (re)encenação no contexto da tradição: "Uma vez que a própria tradição constitui-se como um conjunto de encenações em constante renovação, quando tratarmos das encenações provocadas ou performadas pelo e para o artefato fílmico, usaremos o termo "(re)encenação"”. Entretanto, mais à frente, o termo encenação será empregado por ser mais adequado para as situações em que Vincent Carelli trabalha com as "encenações de conflitos". 
Esse dispositivo, ao colocar diante do Outro a sua imagem em uma espectatorialidade em abismo, sendo um leitmotiv em toda a obra (de $O$ espírito $d a$ TV, 1990; a Desterro Guarani, 2011) e não apenas em um filme específico (em A festa da moça, o jogo de espelhos repete-se mais duas vezes), provoca uma multiplicidade de olhares que adensa o ato de ver e de se perceber com o Outro. Promove fricções perceptivas na autoimagem à medida que os povos se veem no material bruto do ritual da menina moça - como analisa o narrador em off no filme de apresentação Vídeo nas Aldeias (1988), que, no modo reportagem, faz um apanhado do projeto ainda no começo de sua execução nas diversas aldeias já visitadas como programa de intervenção do CTI. Nesse vídeo, revemos o trecho de A festa da moça, quando os Nambikwara (auto)avaliam o ritual que envolve as meninas que acabam de menstruar e precisam ser preparadas para a reclusão e, em seguida, são entregues ao grupo visitante que, simbolicamente, delas se apropria, desmancha a maloca e as retira do confinamento.

Essa é uma sequência inevitável na tradição dos filmes sobre o Outro, que tem como prática apresentá-lo às gravações da sua própria imagem, saber se o recorte do cineasta corresponde ao "olhar dele sobre o mundo vivido e imaginado por ele" (Caixeta de Queiroz, 2008: 103). Nesse contexto, os Nambikwara percebem fissuras no seu mundo, refletem sobre as suas performances e o hábito de se vestirem como brancos, que encobre os adereços e as pinturas corporais transfigurando o ritual que deve ser (re)encenado. Assim, a (re)encenação em $A$ festa da moça contamina a narrativa e o próprio rito - transfigurando-os em seus aspectos iniciais e primários ${ }^{22}$. Como uma das etapas do ritual de iniciação feminina consiste no resgate da menina, o que acontece na segunda (re)encenação é que não temos mais a motivação da festa, pois já visionamos com o Outro a purificação de um corpo já na puberdade, em reclusão, ser resgatado da maloca que a guardava. Nesse segundo momento, o que existe é apenas a (re)encenação em si, que, pela segunda vez, refaz o resgate da menina da maloca desmanchada pelo grupo visitante - como vimos em uma sequência de euforia, movimentação e ação dos corpos embebidos pelo ritual que chegava ao fim.

Por isso, a segunda e a terceira (re)encenações só têm valor em si ou, especialmente olhando para o filme, uma finalidade performática, que é a de inscrever, no corpo narrativo e na materialidade da imagem, o "modo correto"

22. As dimensões aqui aplicadas ao termo transfiguração, ou seja, o ritual descaracterizado e refeito como marcas das diversas temporalidades, mutabilidades e adaptações pelas quais passam os povos indígenas, exceto a dimensão narrativa-formal-cinematográfica cuja aplicação do termo se dá num plano metafórico, encerram (nas devidas aproximações e níveis em que se encontram os Nambikwara) o conceito de "transfiguração étnica" do antropólogo Darcy Ribeiro (2015). 
de (re)encenar a tradição. Principalmente, porque na primeira vez, como vimos no monitor de TV, o ritual estava corrompido, segundo a avaliação dos próprios Nambikwara. Ao olharem-se, como que em um espelho, identificam fissuras em sua base cultural, a partir das vestimentais e do uso de adereços sobre os seus corpos, decorrentes dos modos de ser e de se vestir como brancos. Em outro contexto, a título de comparação com o que acontece em outra latitude étnica e fílmica, Dominique Gallois e Vincent Carelli (1991: 33) analisam a modulação da (auto)imagem pelos Wajãpi ${ }^{23}$ como "recurso na política de afirmação" identitária (pinturas corporais, posição guerreira, autenticidade cultural). Mas, em A festa da moça, as (re)encenações tornam a performance em si o seu próprio referente, sendo, consequentemente, menos "reificação da tradição", "ação catalisadora" e/ou "performar-se como índio" (Cesar, 2012: 94/91/95). O que entra em cena, mesmo que subjazam desejos de reconstituição, de catarse coletiva e preocupação em vestir-se de tradição, portanto, é o jogo cênico dos corpos no espaço e no tempo - em euforia, em transe, em abismo, objetivando sua percepção sobre o "como deveria ser" e, no decorrer das ações e reencenações, parodiando os parentes dos diversos grupos que buscavam a sua maneira o "modo correto" de colocar em imagem o ritual da menina moça.

\section{O lugar do Outro}

Três décadas depois, Vincent Carelli voltou ao procedimento da (re)encenação.

Em Krohokrenhum, eu não posso morrer de graça (2011), utiliza imagens do documentário Pemp (1988), que conta a saga dos Gavião Parkatêjê 24 do contato em 1957 à autonomia político-econômica, no final dos anos 1980, quando a comunidade negociou contratos milionários com a Eletronorte e a Vale, respectivamente, para a passagem de uma linha de transmissão ligando Marabá-PA a Imperatriz-MA e da linha férrea do Projeto Carajás. Por meio dos arquivos inseridos no filme biográfico sobre o líder dos Gavião Parkatêjê, vemo-lo em movimento no centro da aldeia, com os seus gestos e jogos de

23. Os Wajãpi, que integram a família linguística Tupi-Guarani, habitam o Amapá-AP e o Pará-PA, bem como a Guiana Francesa. Compreendem, respectivamente, uma população de 1.221 (Siasi/Sesai, 2014) e 950 indivíduos (Grenand, 2009). A história do contato é marcada pela chegada da Funai, em 1973 e, a partir dos anos 1980, de garimpeiros (Povos Indígenas do Brasil / Instituto Socioambiental-IS A, 2018).

24. Os Gavião Parkatêjê (o povo de jusante), que integram a família linguística Jê, habitam o Pará-PA, compreendem uma população de 645 indivíduos (Siasi/Sesai, 2014). A história do contato é marcada, no final dos anos 1950, pela chegada do SPI (Povos Indígenas do Brasil / Instituto Socioambiental-IS A, 2018). 
olhares criando uma tensão performática sem fim e encenando o conflito com outro povo quando ainda eram isolados. Se, em seu núcleo, o ato de encenar constitui a tradição documentária (Ramos, 2005: 160), revisitar o conflito, como um intérprete de si da história do seu povo, já faz parte da tradição do documentário brasileiro. No segmento final de Terra dos Índios (1979), de Zelito Vianna, por exemplo, registro e encenação, em simbiose, entram em cena e ocupam todo o espaço fílmico e domínio do corpo. O corte final abre espaço para um indígena que, movimentando-se em sua própria mise en scène ou auto-mise en scène (Comolli, 2008; France, 1998; Freire, 2011), interpreta os personagens de um combate que ocorrera na região contra um fazendeiro e modula o espaço fílmico como espaço de fabulação ${ }^{25}$.

Em um jogo de espelhos, entre o campo, o fora de campo e o extracampo, as lentes do diretor de fotografia Affonso Beato, diante de um intérprete de si mesmo, capturam todos os fantasmas da questão indígena no Brasil, (trans)figurada na realidade física e imaterial transcorrendo "por dentro", "com" e "a partir" da câmera. Nos domínios das escolhas do Outro, capturam a performance em movimento daquele indígena: suas ações, seus gestos e suas expressões - de ressonâncias históricas no território da imagem em um regime único de auto-mise en scène acolhido pelo diretor no corte final. Entre a evidência e a intervenção criativa, escreveria Manuela Penafria (1999: 23), esse jogo cênico acontece no "documentário, pois, [este] é um espaço onde se abre a possibilidade de constantemente se construírem, reconstruírem, criarem, recriarem e combinarem formas de ordenação que dele fizerem parte". No âmbito do VNA, a encenação do confronto ganha contornos inesperados, seja quando os indígenas se posicionam no outro lado do espelho para criarem imagens ou participam dos filmes como personagens-objetos refletivos pela magia especular do cinema. O vídeo Antropofagia Visual nos dá a exata medida, ao apresentar os Enawenê-nawê que não só encenam o ataque de outro povo à sua aldeia (em um movimento cênico/fílmico quase épico). Mas, com auxílio da equipe de gravação, elaboram uma ficção com enredo e ações, na qual enredam um mundo real e imaginário e (re)encenam a experiência histórica, ao mesmo tempo, fabular, quase mítica e sem rastros de memória.

25. É importante lembrar que a mise en scène é resultado de uma relação: "A mise em scène é um fato compartilhado, uma relação. Algo que se faz junto, e não apenas por um, o cineasta, contra outros, os personagens. Aquele que filma tem como tarefa acolher as mise en scènes que aqueles que estão sendo filmados regulam, mais ou menos conscientes disso, e as dramaturgias necessárias àquilo que dizem - que eles são, afinal de contas, capazes de dar, e desejosos de fazer sentir" (Comolli, 2008: 60). 
Em Pirinop, meu primeiro contato (2007), de Mari Corrêa e Karané Ikpeng ${ }^{26}$, que coloca em cena a história dos Ikpeng ${ }^{27}$ depois da chegada dos irmãos Villas-Bôas, Cláudio e Orlando, na região próxima ao Rio Xingu, Mato Grosso-MT (além da saga do exílio, as lembranças e o retorno à terra abandonada), a encenação é modulada pela montagem e não pela performance de um corpo. Intercalando materiais de arquivo com imagens contemporâneas, Pirinop materializa o pensamento (as lembranças, a memória, o afeto e a dor do exílio) da velha Ikpeng, quando do seu retorno à terra originária - a partir de planos do seu rosto já velho alternado com jovens indígenas se banhando no mesmo rio em que, em tela, vemo-la atravessá-lo sobre um barco. Entre o passado (arquivado em imagens) e o presente (das filmagens contemporâneas do seu corpo), temos o desejo do registro e do artifício em uma só e mesma materialidade narrativa, como trabalhamos em outro momento depois que colocamos Martírio e Serras da Desordem (2006) face a face (Felipe, 2018b). Nos exemplos anteriores (A festa da moça; Terra dos Índios), o ponto de vista do Outro se estabelece quando ocorre a atenuação - já que não pode haver o apagamento - do ponto de vista de quem filma (do olhar dominador do diretor), que, por sua vez, abre espaço à voz de quem é filmado, ao apresentar "as versões do grupo sobre sua história, suas opções para o futuro e não as interpretações que o antropólogo [ou o cineasta] faz dessa história, ou desse futuro" (Gallois; Carelli, 1995: 70). Portanto, para esse jogo de partilha se efetivar, precisa haver: articulação entre as diversas demandas; fricções entre os pontos de vistas envolvidos; e abertura para que as demandas do Outro, que estejam relacionadas a nossa sociedade, também entrem em cena (Gallois; Carelli, 1995: 70-71).

Nos segmentos de (re)encenação, A festa da moça se transforma em outro filme. Ao colocar a questão indígena em foco, o próprio Vincent já explicara que não havia uma etnografia pura ${ }^{28}$. Se antes, como nos antigos filmes

26. Mari Corrêa, que trabalhara nos Atelier Varan como montadora profissional, dirigiu, entre outros, Uma escola Hunikuin (2008 - com Zezinho Yube, Vincent Carelli e Ernesto de Carvalho), além de Para os nossos netos (2008) e De volta à terra boa (2008) - ambos com Vincent. Em 1998, entrou para o VNA e, em 2009, criou o Instituto Catitu (IC) para trabalhar com mulheres indígenas no Xingu. Um nome fundamental na passagem do VNA de projeto a ONG (ou escola de cinema).

27. O povo Ikpeng, que também é sua autodenominação, pertence a família linguística Karib, habita no Estado do Mato Grosso-MT e compreende uma população com cerca de 500 indivíduos (Siasi/Sesai, 2014). A história do contato é marcada pela chegada dos irmãos Villas-Bôas e sua transferência para o Parque do Xingu (Povos Indígenas do Brasil / Instituto Socioambiental-ISA, 2018).

28. Vincent em entrevista à revista ECO-Pós da UFRJ: "Era um filme sobre o processo. E as pessoas que assistiam ao filme cobravam: 'Mas e o ritual'? (Cesar et al., 2017: 251). 
etnográficos, as manifestações culturais estavam no centro da câmera, agora Vincent confronta a problemática do contato, acompanhando a evolução dos eventos do mundo indígena diante das suas lentes - ou seguindo o que Fernão Pessoa Ramos (2018: 58) chamou de "indeterminação do acontecer" quando analisou outras latitudes cinematográficas. Do alto do penhasco, com o líder Pedro Mãmãindê apontando para o interior da floresta e a câmera esquadrinhando o seu olhar e movimentos, sabemos quando o trauma histórico se instalou com a expropriação do patrimônio territorial e a redução populacional Nambikwara: de 10 mil indivíduos no início do século 20, restaram apenas $600^{29}$. Entre um segmento e outro, ao "registro etnográfico" sucedem-se sequências que dão corpo ao filme político, como as rodas de conversas das lideranças que debatem o direito territorial. Antes que A festa da moça volte ao andamento mais etnográfico, com o ritual da furação de lábio e nariz provocado pela catarse coletiva decorrente da presença da câmera, a dimensão política culmina com um dos subgrupos Nambikwara chegando ao seu território, que foi retomado em um processo de resistência que lhes devolveu o habitat sagrado violado.

Como assinalamos, a questão indígena permeia a câmera de Vincent mesmo quando registra as tradições, quando o que comumente acontece é prenderse a uma etnografia fechada no mundo histórico e cultural de uma comunidade. Na mesma perspectiva política que invade A festa da moça, quase 15 anos depois de Yãkwa, o banquete dos espíritos (1995), de Virgínia Valadão ${ }^{30}$, Vincent Carelli testemunha um dos mais longos rituais indígenas da Amazônia (dura sete meses), a partir de um registro gemelar sobre o mesmo ritual Enawenê-nawê $\hat{~}^{31}$. Contudo, enquanto em Yãkwa, o banquete dos espíritos, temos um filme que se desenrola em tons etnográficos, em Yaõkwa

29. A cronologia do genocídio apresentada por Lévi-Strauss (1996: 278): "Em 1915, Rondon calculara [a população Nambikwara] em 20 mil [...] Contudo, em novembro de 1929 surgiu uma epidemia de gripe [...] A doença evoluiu para uma forma de edema pulmonar, e trezentos índios morreram em 48 horas [...] Dos mil Sabanê outrora conhecidos, só subsistiam dezenove homens em 1938, com suas mulheres e seus filhos [...] Um grande grupo instalado perto de Três Buritis foi liquidado pela gripe de 1927, com exceção de seis ou sete pessoas, das quais só três ainda estavam vivas em 1938. O grupo Tarundê [subgrupo Nambikwara], no passado um dos mais importantes, contava doze homens (mais as mulheres e as crianças) em 1936; desses doze homens, quatro sobreviviam em 1939".

30. A antropóloga Virgínia Valadão (1952-1998), além de Yãkwa, o banquete dosespíritos, dirigiu no âmbito do VNA enquanto programa do CTI, Wai'a - O segredo dos homens (1987) e Morayngava (1997 - com Regina Muller), respectivamente, sobre as tradições Xavante e Assurini. Uma das fundadoras do VNA, era também esposa de Vincent Carelli e faleceu, prematuramente, no final da década de 1990.

31. Os Enawenê-nawê, que integram a família linguística Aruak, habitam o Mato GrossoMT, compreendem uma população de 737 indivíduos (Siasi/Sesai, 2014). A história do contato 
(2009), de Vincent Carelli, a questão indígena se inscreve, aparentemente, no entremeio da mesma forma etnográfica sobre o ritual no centro da produção material daquela comunidade localizada no Mato Grosso-MT. Nos créditos finais, por exemplo, lemos que são 77 hidrelétricas a ameaçarem a integridade do patrimônio cultural dos Enawenê-nawê, que depende da integridade do seu ecossistema e da biodiversidade. Entretanto, longe de se reduzir a um dado estatístico, de forma contundente, uma sequência é emblemática dos desvios narrativos (ou da mudança de rota) da escritura de Vincent, quando, em quadro, abre espaço para que se instale a problemática da questão indígena. É quando, ao acompanhar uma espécie de unidade de vigilância territorial nativa pelo curso do Rio Preto, suas lentes, em terra, constatam a natureza violada pelas madeireiras e o avanço de fazendeiros na Terra Indígena (TI) Enawenê-nawê.

Mas mais do que isso: de um dos indígenas, que desce da canoa e logo se volta para o câmera, escutamos juntamente com o diretor o que ele certamente não esperava: "Vocês brancos estão fazendo tudo errado!". Com o olhar voltado para a instância que o filma e, ao mesmo tempo, para quem está do lado de cá do espelho, enquadrando todos nós no problema, há um reenquadramento. Principalmente, porque aquele Enawenê-nawê se movimenta no que Ruben Caixeta de Queiroz (2008: 116) chamou de "antropologia reversa", ou seja, o "olhar certeiro do índio sobre o olhar colonizador do branco" -, pois, nesses casos, "são os índios que enquadram o 'olhar do branco' e revelam não só sua dimensão histórica, mas sua presença real no mundo de hoje”. É, a seu modo, uma sequência reveladora das relações de poder que impregnam o documentário, pois "Aqueles ou aquelas que empunham a câmera detém um poder inquestionável sobre aqueles ou aquelas que são objeto de sua mirada [sem que estes últimos deixem de se opor] [...] a certas imposições ou mesmo sugestões do documentarista" (Freire, 2011: 30-31). Campo de força e de poder que, no cinema documental, se evidencia quando a visão do Outro é acolhida como resistência, o que só é possível porque a câmera de Vincent nunca foi uma "mosca na parede", quando o cinema direto ${ }^{32}$, face à realidade filmada, requisitaria sua invisibilidade e tenderia a anular qualquer envolvimento.

Talvez, no Vídeo nas Aldeias, uma exceção seja Shomotsi (2001), de Wewito Piyãko, no qual o cineasta Ashaninka acompanha o cotidiano do seu tio

é marcada pela presença de garimpeiros e missionários jesuítas (Povos Indígenas do Brasil / Instituto Socioambiental-ISA, 2018).

32. O modo direto (ou observativo), em linhas, caracteriza-se pela "observação espontânea da experiência vivida, sem interferência dos diretores, isolados na "posição de observador(es)'". "O que vemos é o que estava lá, ou assim nos parece", preservando a duração real dos acontecimentos (Nichols, 2005: 146-153). O cinema direto americano consagrou o modo observativo com Primary (1960, de Robert Drew) (Penafria, 1999: 63). 
(que dá título ao filme) na Aldeia Apiwtxa, no Acre-AC, a partir da câmera no modo observacional. No entanto, essa neutralidade aparente acontece só em parte, pois a presença da câmera é denunciada o tempo todo pelo personagem. Como sabemos, "nenhuma atividade filmada - cujo agente se sabe filmado escapa aos efeitos da presença do cineasta [...] mesmo o documentário, é sempre o resultado do afrontamento de duas mises en scène, a das pessoas filmadas (auto-mise en scène), e a do cineasta (mise en scène)" (France, 1998: 393). Diante das lentes dos cineastas indígenas, a consciência da câmera é escancarada em Pi'õnhitsi, mulheres xavante sem nome (2009), de Divino Tserewahú, quando um dos velhos da aldeia de Sangradouro-MT ameaça quebrá-la, caso o diretor não providencie shorts (sic.) para os rapazes da festa ${ }^{33}$. Na poética de Vincent Carelli, essa reação ótica do Outro aparece também em De volta à terra boa (2008, em codireção com Mari Corrêa), quando um velho Panará ${ }^{34}$ olha para o centro da objetiva e diz: "Vocês, brancos, acabaram com as nossas terras".

Dada a vivência de Vincent com os povos originários ao longo das décadas, quando em Pi'ónhitsi, mulheres xavante sem nome e em De volta à terra boa, é forte a sequência em que o câmera ${ }^{35}$ é incluído no lugar do predador ambiental da problemática da questão indígena. Ao optar por preservar no corte final a crítica que o inclui, a verdade é que, em Yaõkwa, Vincent Carelli inscreve na materialidade narrativa o mundo do qual, inevitavelmente, faz parte e que é responsável pela degradação do patrimônio cultural e territorial do povo Enawenê-nawê. Uma sequência que se sobressai em densidade e revelação das relações entre dois mundos complementares distantes e, sobretudo, da consciência e contundência do Outro nesse processo de comportamento profílmico (France, 1998), antropologia reversa (Caixeta de Queiroz, 2008), acolhimento da mise en scène do Outro (Comolli, 2008) e de rotação do olhar (Schefer, 2016). Nesse momento, aquele Enawenê-nawê, de forma reativa, ainda que espontânea, com a força do seu olhar e de suas palavras que atravessam a tela, ao voltar-se para quem responde pelas lentes que o filmavam e, ao mesmo tempo, para quem está do lado de cá do espelho que trinca e se parte, coloca todos nós atrás daquela câmera.

33. O povo Xavante, que pertence a família linguística Jê, habita o Estado do Mato GrossoMT, tem uma população com cerca de 19 mil indivíduos (Siasi/Sesai, 2014) e se reconhece pela autodenominação A'uwe (Povos Indígenas do Brasil / Instituto Socioambiental-ISA, 2018).

34. O povo Panará, que pertence a família linguística Jê, habita territórios do Mato GrossoMT e do Pará-PA e tem uma população de aproximadamente 600 indivíduos (Siasi/Sesai, 2014) (Povos Indígenas do Brasil / Instituto Socioambiental-IS A, 2018).

35. A fotografia de Yaõkwa é de Altair Paixão, Tiago Campos Torres e Vincent Carelli. 


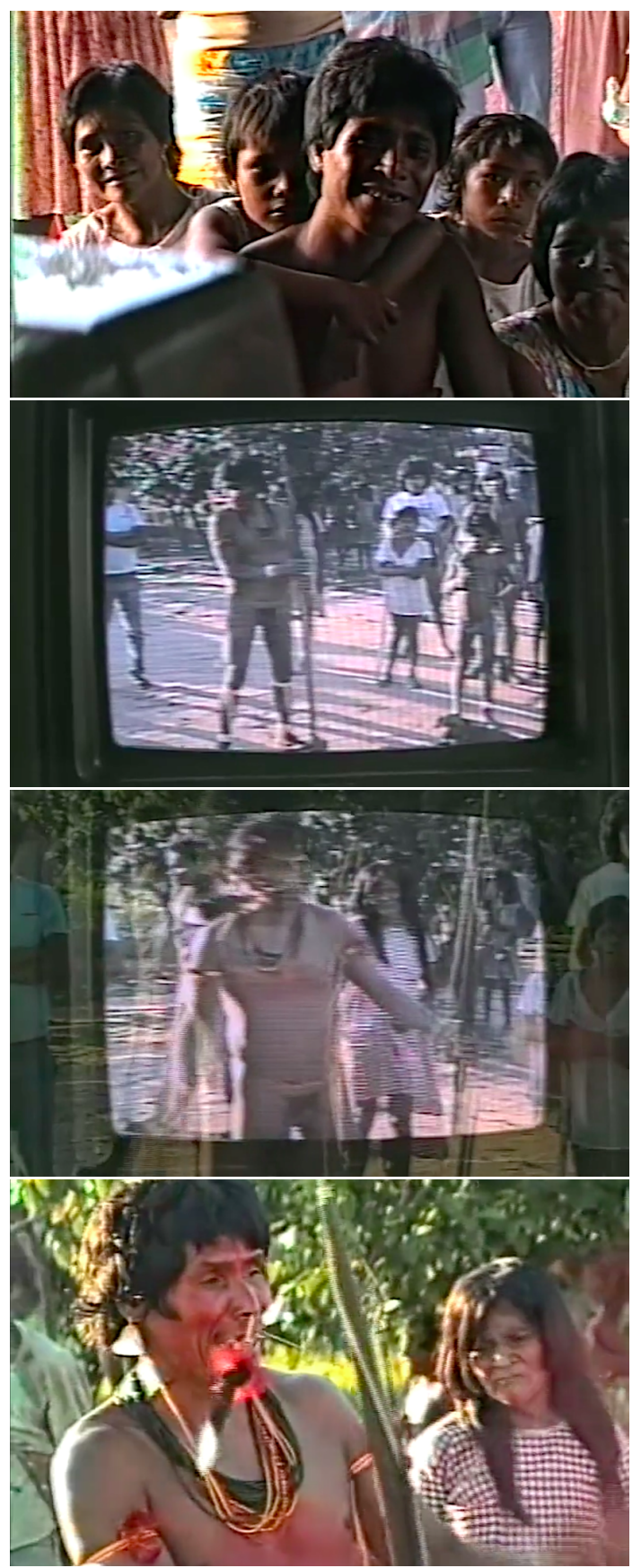

Painel 1. A festa da moça I Fotogramas (C) VNA 
Se a questão indígena se revela mesmo quando, aparentemente, Vincent Carelli trabalha com filmes de cunho etnográfico, a história do conflito está presente (ainda que de forma implícita) no que, em sua filmografia, podemos chamar de filmes digressivos (outra mudança de rota em sua escritura, mas, neste caso, no âmbito filmográfico) - como, por exemplo, vemos em Qual é o jeito Zé (1990) e Ninguém como carvão (1991, dirigido com Murilo Santos), respectivamente, sobre o conflito de terras entre camponeses e fazendeiros e o trabalho degradante em carvoarias em meio à Amazônia. Isso se dá porque são com esses personagens, sem terras e do mundo do garimpo, que os povos originários entram em confronto, relacionam-se e acabam convivendo, ainda que involuntariamente, em função da problemática ambiental e das invasões dos seus territórios, como também vemos em Meu amigo garimpeiro (1994), de Dominique Gallois ${ }^{36}$, sobre as comunidades Wajãpi, do Amapá, em confronto com essa categoria mineradora, que adentra os territórios demarcados e polui os rios com mercúrio. Aparentemente, afastando-se das comunidades nativas, Vincent vai construindo um contexto que é mais complexo e está totalmente relacionado à problemática cultural e territorial envolta das comunidades indígenas, o que já vinha sendo assinalado, por exemplo, em Pemp, quando os camponeses que chegaram com o Complexo da Vale naquela região do Pará ocuparam como posseiros as terras que pertenciam a TI Gavião Parkatêjê.

\section{Autorreferencialidade}

Nos muitos nichos analíticos de A festa da moça, que é um ponto de partida neste estudo sobre o cinema documentário de Vincent Carelli, a multiplicidade de olhares provoca em cadeia o processo perceptivo que se desdobra do espectador em direção aos Nambikwara que, no centro, remete para outra realidade veiculada pelo monitor de TV implantado na aldeia de um dos grupos participantes do evento. Nesse dispositivo, incluem-se: (1) o diretor e a equipe de produção que, com o Outro, vê o que até então era apenas um registro de uma festa indígena; (2) os Nambikwara, que se veem e (auto)avaliam seus ritos, corpos e, em suma, sua imagem; e (3) nós, espectadores, que entramos nessa cadeia ótica que se desdobra, funda-se e se transforma. Assim, em A festa da moça, Vincent Carelli leva a mise en abyme ao limite. Se o quadro primitivo gerado pela câmera se constitui na imagem primária dos Nambikwara (é por ele que aquele povo nos é apresentado, antes de inscritos no monitor de TV,

36. Professora do Departamento de Antropologia da USP, a antropóloga Dominique Tilkin Gallois realizou, além de Meu amigo garimpeiro, em parceria com Vincent, A Arca dos Zo'e, Placa não fala (1996) e Segredos da Mata (1998) sobre os Wajãpi. Figura central do CTI, Gallois é uma das fundadoras do vNA. 
ou seja, na tela dentro da tela), o diálogo entre a multiplicidade de quadros e olhares cria, em abismo, um vórtice perceptivo, no qual os indígenas olham-se como se estivessem diante do espelho em labirinto, que os reflete, refrata e os transfigura.

Um jogo ótico ganha em complexidade e se enraíza porque a imagem ontológica (resultante do corte final) reaparece no monitor de TV (como material bruto, que foi gravado e foi exibido na aldeia) antes de, paradoxalmente, ser finalizada na montagem e ser encerrada no produto final. O inverso, adensando o diálogo entre material bruto e finalizado, também acontece. Do pequeno aparelho de televisão para o quadro da câmera, preenchendo todo o espaço até "tocar" as bordas do quadro primário, a (re)encenação (ou os fatos das micro e diversas situações registrados no documentário) preenche o campo da imagem. Assim, a dimensão imagética serve de contexto para a própria imagem, sem mediações que não sejam as da sua própria materialidade narrativa. Nesse campo, as fusões de materiais finalizados e brutos desestabilizam não apenas a percepção dos indígenas, mas a própria noção sobre o que constitui uma obra acabada, ou o produto final, no sentido da montagem.

Principalmente, porque, em A festa da moça, há um jogo constante entre material bruto (visto pelos Nambikwara) e finalizado (que antecede e sucede as imagens não editadas e com elas se confundem). Retroalimentam-se, assim, sob a lógica que, no caso do cinema documentário de Vincent Carelli e dos cineastas e coletivos indígenas de cinema - o caso mais notável é o do Coletivo Guarani Mbya, faz os diversos materiais visuais perpassarem de uma obra a outra. A exemplo de $O$ espírito da $T V$ que, ao apresentar os Wajãpi em um mesmo contexto de recepção, transborda no filme $A$ arca dos $Z o$ 'é, com os anteriores indo visitar o povo Zo'é - de matriz tupi-guarani - recém contatado. É nesse momento, ainda inicial na filmografia de Vincent, que acontece o que ele propunha, em termos de uma práxis fílmica-comunitária em rede, como sendo um dos veios do Vídeo nas Aldeias, a saber, o intercâmbio de imagens provocando o intercâmbio entre os povos (Carelli, 2011: 47-48). Se por um lado existem em si, como filmes dotados de autonomia, essas obras iniciais do VNA, por outro, ganham maior relevo quando vistos em interdependência documental, pois o "intercâmbio de imagens" que provoca o "intercâmbio presencial" só se completa em série.

Isso ocorre porque há a reutilização permanente de imagens, como, por exemplo, observamos, em $O$ espírito $d a T V$, no monitor instalado no centro da aldeia Wajãpi, da mesma forma que fora instalado no coração da aldeia Nambikwara. A partir do aparelho de televisão, que vemos em caixas dentro de uma canoa logo na abertura do filme, ser carregado por dois indígenas pelo espaço 
da aldeia e depois instalado com a comunidade diante dos seus traços luminosos, pululam trechos de A festa da moça e de Pemp, bem como das grandes rezas dos Guarani Kaiowá. Na visão dos próprios Wajãpi, que nos ajudam a perceber o que apenas sua percepção identifica e que víamos com olhos ocidentais como uma "simples" manifestação de canto, dança e reza, os Kaiowá em tela estão tomados por espíritos que descem na batida do chocalho, cuja sonoridade entremeada nos corpos revela o fervor religioso entrecruzado no fervor político. Filmados no final dos anos 1980, só reveríamos esses trechos dos Guarani Kaiowá em Martírio - praticamente, 26 anos depois, quando Vincent reutiliza esses planos para iniciar o seu mais emblemático documentário.

Já Corumbiara, nesse processo de reutilização imagética, formado por "pedaços" filmados ao longo de três décadas, sem que se tivesse em vista a obra como a conhecemos, é o protótipo da poética de Vincent de resgatar materiais, aparentemente, descartados. Por sinal, esse documentário, cuja estrutura narrativa se dilata no tempo, inicia com o final de A festa da moça, como se o continuasse; e como se prolongasse as histórias dos seus personagens (do líder Pedro Mãmãindê), pois a sequência que encerra o primeiro trabalho de Vincent inicia Corumbiara, com trechos editados e imagens adicionais - que só então visionamos e temos contato depois de mais de três décadas de sua gravação. Observação que nos aproxima da perspectiva de cinema-processo de retomada de imagens delineado pela pesquisadora Clarisse Alvarenga (2017), mas com o adendo de que expandimos suas dimensões conceituais e fílmicas, pois, no cinema de Vincent Carelli, esse reuso ocorre de um documentário a outro, entre os filmes, e não apenas dentro do mesmo corpo narrativo documental, a partir dos "restos" que sobraram das obras precedentes em um processo também de retomada... cinematográfica ${ }^{37}$.

37. "São filmes-processo não simplesmente pelo fato de terem sido realizados durante extenso período de produção - apesar desse ser um traço importante. Para além desse princípio, essas obras introjetam e inscrevem aspectos das experiências vividas e compartilhadas, assim como deixam entrever o tempo que atravessa seus processos de realização [...] [São filmes] 'marcados pela história' [...] Nesse caso, a marca que a história deixa nos filmes convive, de certa forma, com a marca que os filmes deixam na história” (Alvarenga, 2017: 77). 


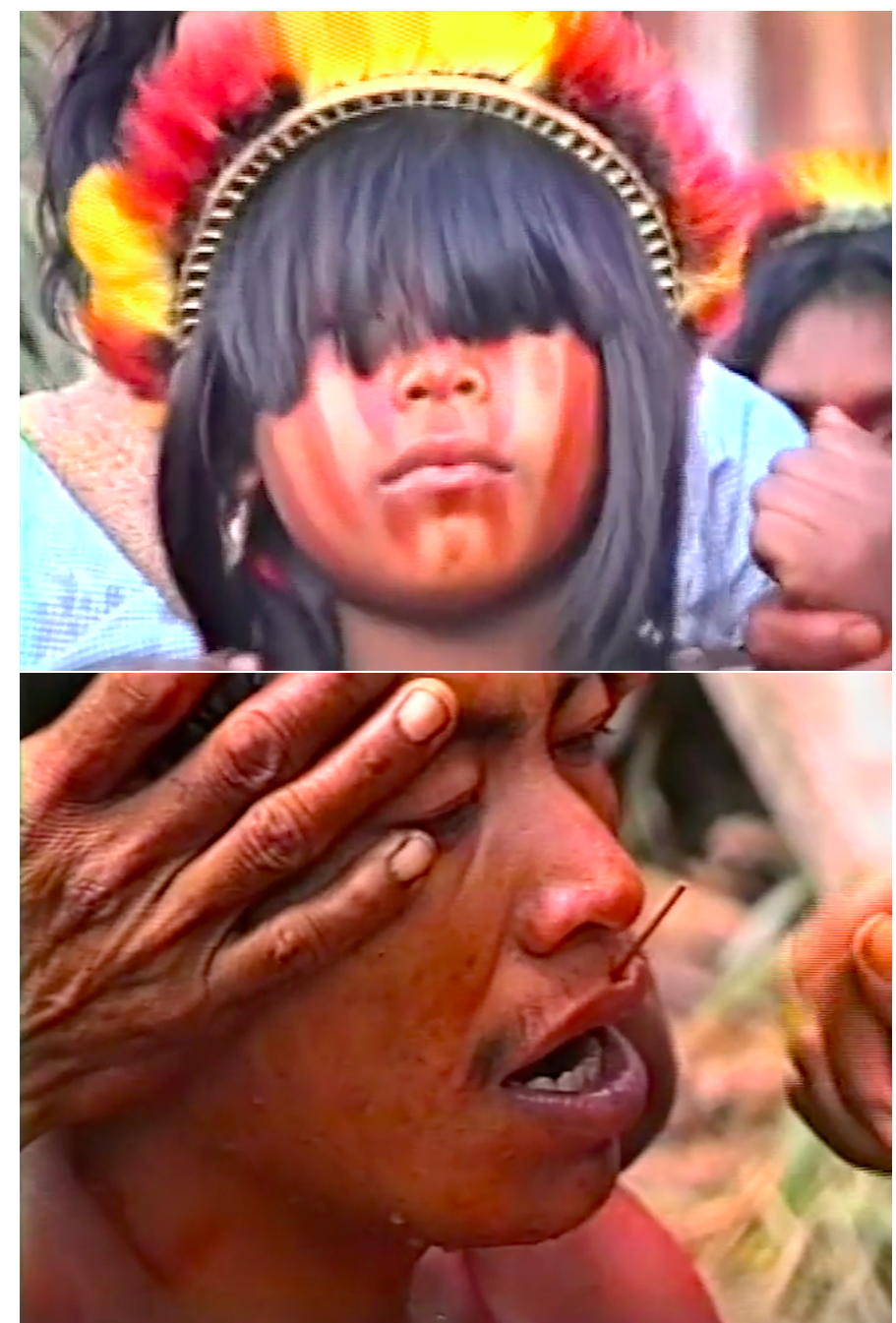

Painel 2. A festa da moça I Fotogramas (C) VNA

De modo diferente, mas assumindo essa concepção de cinema-processo expandido, a trilogia do Capitão Krohokrenhum obedece ao sistema de reutilização de materiais interligando as três obras até então realizadas. Além de Pemp e Krohokrenhum: eu não posso morrer de graça, o filme Eu já fui seu irmão compõe a trinca, na qual acompanhamos o líder dos Gavião Parkatêjê. Nascido em grupos ainda isolados, cujo contato se deu em 1957, com a mediação do Serviço de Proteção ao Índio (SPI), Krohokrenhum praticamente envelheceu dentro das imagens: um personagem capturado por quatro décadas pelo 
cinema (e também pela fotografia), de um filme a outro, cuja transformação do corpo, o engenho intelectual e as estratégias de resistência acompanhamos em quadros, fotos, fotogramas, movimentos de câmera, depoimentos, angulações, encenações, performances etc. Krohokrenhum é, assim, talvez o personagem mais longevo da história do documentário brasileiro ${ }^{38}$. Se se confirmar a finalização de Adeus, Capitão, que encerrará, podemos assim concluir, uma tetralogia ${ }^{39}$ sobre o personagem dos Gavião, outras nuances podem ser desfiadas desse novelo mais amplo. O que, por sua vez, ampliará o sistema de reutilização de materiais brutos ou finalizados, uma vez que apresenta outra face da práxis de retroalimentação de planos, sequências, trechos e circunstâncias fílmicas, como se estivéssemos em um sistema ou organismo que se movimenta em uníssono. No âmbito do VNA, esse sistema chega ao paroxismo com o Coletivo Guarani Mbya ${ }^{40}$, a partir de um jogo de retroalimentação de imagens de filme a filme, que será objeto de análise em outro momento.

Se A festa da moça se divide uma primeira vez, ao passar do filme etnográfico ao filme político, o que vemos já próximo do final são desdobramentos de outras formas documentais desencadeados pela presença da câmera que dá corpo à realidade, que sem ela não existiria naquele momento: o ritual da furação de lábio e nariz - imagem primal do povo Nambikwara que, na fala de um

38. Talvez, tenha quem objete com Elizabeth Teixeira, que já era retratada, desde o início da década de 1960, por Eduardo Coutinho, quando tentou filmar - o "primeiro" Cabra - Marcado para Morrer, no qual interpretava a si mesma em uma ficção política sobre as Ligas Camponesas e o assassinato do seu marido. Elizabeth voltou a ser filmada em 1981, quando Coutinho a descobre clandestina em São Rafael-RN e a torna personagem central do documentário Cabra Marcado para Morrer (1984); e, nos anos 2010, em A família de Elizabeth Teixeira (2013), ao reencontrá-la depois de décadas. Entretanto, se considerarmos os registros fotográficos do Serviço do SPI que vemos em Pemp e em Krohokrenhum: eu não posso morrer de graça, o capitão dos Gavião atravessa mais de meio século entre-filmes, entre-imagens. Aliás, ao divisarmos a sua fotografia ainda jovem e de outros Gavião Parkatêjê semi-isolados, podemos dizer que divisamos não um personagem de 1957 (ano do contato), mas de 500 anos de história de um povo, que, por opção, sobreviveu a cinco séculos isolado, sem contato com o mundo dos brancos.

39. Nesse caso, Adeus, Capitão integrará, possivelmente, duas tetralogias. Ao lado de Corumbiara, Martírio e o filme sobre os Xikrin Kayapó, uma primeira tetralogia sobre o genocídio dos povos originários. A segunda, enfim, constituirá a tetralogia sobre o Capitão Krohokrenhum.

40. Os Guarani Mbya, que integram a família linguística Tupi-Gurani, vivem na Argentina, Paraguai e Brasil (em sete estados). Compreendem, respectivamente, uma população de 2.147 (INDEC, 2010), 21.422 (II Censo Nacional de Poblacion y Viviendas, 2012) e 7.000 (Funasa/Funai, 2008) indivíduos. A história do contato remonta ao Século XVI e é marcada pela presença das missões jesuítas e pelas guerras guaranítcas (Povos Indígenas do Brasil / Instituto Socioambiental-ISA, 2018). 
indígena participante, é o que os distingue como povo. ${ }^{41}$ É um das sequências mágicas do primeiro filme de Vincent, pois desencadeia uma prática cultural há muito esquecida, sem vínculo cotidiano com as novas gerações, e que o seu filme a recoloca no palco atual da história Nambikwara e abre espaço para a consolidação de elos identitários. Nesse momento, Vincent transforma mais uma vez A festa da moça, que já havia se transformado outras vezes, e o coloca na lógica do cine-transe de Jean Rouch. Desse modo, não era mais uma realidade que precisava ser (re)encenada diante da câmera. No processo de furação de lábios e narizes, com a planificação moldada em primeiros planos e close-ups dos rostos sendo perfurados, tradição cultural e filmagem confluem e se tornam interdependentes, como se fossem um mesmo corpo ${ }^{42}$. Em outra latitude do Vídeo nas Aldeias, observamos que filmar, criar documentos e fazer existir em imagem, com o intuito de que fique o registro para as gerações posteriores como A festa da moça abrigou o ritual "perdido" dos Nambikwara, tem sido esse o cerne do cinema do cineasta indígena Divino Tserewahú. Suas imagens, para além das fricções que rondam o processo documentário dos seus filmes, são praticamente documentos dos três grandes rituais do povo Xavante, do Mato Grosso-MT: Wapté Mnhõnõ, a iniciação do jovem xavante (1999); Wai'á Rini, o poder do sonho (2001); e Pi'ônhitsi, mulheres xavante sem nome.

Em A festa da moça, emerge uma outra problemática do VNA: a desintegração dos modos de ser e saber do Outro. Mais um elemento da questão indígena que atravessa o cinema de Vincent Carelli. Sobretudo porque, a partir de Quijano (2005), sabemos que apenas a expropriação territorial não é central na problemática da diferença cultural no contexto ameríndio, pois passou a ser necessário expropriar, ao mesmo tempo, o patrimônio cultural dos povos originários, suas formas de conhecimento, subjetividade e de aprendizagem cultural. Ao ser destituído de suas especificidades históricas, o Outro foi reduzido à condição de coisa (sem passado, cultura, história), o que torna impensável e continua sendo - o reconhecimento dos saberes indígenas por parte da sociedade nacional, como reconheceu o antropólogo Claude Lévi-Strauss (1996: 274) diante do conhecimento sistematizado e complexo do fabrico de veneno dos Nambikwara que se dá "a partir de uma infusão da película vermelha que

41. A consciência sobre o processo de transformação cultural é latente nos povos originários. Para Vincent (Cesar et al., 2017: 251): “Às vezes, é uma ideia introjetada, de que eles só vão provar que são índios se tiverem uma festa... essa auto-folclorização para corresponder a uma ideia".

42. O próprio Rouch explica o conceito de cine-transe: "Assim, para os Songhay-Zarma, bastante habituados com o cinema, minha pessoa se transforma diante de seus olhos, como se transforma a pessoa dos dançarinos de possessão, até à 'cine-transe' de um filmando o transe real do outro" (France, 1998: 403). 
reveste a raiz de certos strycnos". A tentativa de uma colonização territorial, portanto, não é indissociável da colonização dos modos e das formas de vida de quem não participa dos mesmos valores civilizatórios ocidentais. As políticas assimilacionistas ou integradoras são centrais nos discursos dos Governos representativos de uma certa sociedade nacional, que julga o (auto)isolamento ou afastamento dos povos originários sob os seus parâmetros ocidentais.

Essa problemática, que foi assimilada e revertida - pelo menos no campo da imagem - pelos Nambikwara, Vincent Carelli enfrentou de forma mais direta com Iauaretê, cachoeira das onças (2006). Nesse documentário, ao colocar em cena a colonialidade do ser e do saber como dimensão política das práticas da Igreja Católica junto ao povo amazônico Tariana ${ }^{43}$, o diretor revela a violência "pós-colonial" brutal que se abateu sobre a sua base societária e cultural, com os ritos indígenas sendo substituídos pela evangelização transfigurante. Diante das suas lentes, acompanhamos a luta permanente dos remanescentes que foram expropriados das suas formas de vida e dos seus modos de saber tradicionais. Mas que conseguiram, além do território demarcado, retomar parte do seu patrimônio cultural, na busca da sua autonomia e manifestações culturais "perdidas", como fizeram os Nambikwara ao se verem (quase) transfigurados no decorrer d'A festa da moça. É sublime, em Iauaretê,, cachoeira das onças, a sequência dos Tariana em visita ao Museu do Índio, em Manaus-AM, com a instituição museológica sendo abordada também como espaço de expropriação, quando os indígenas descobrem no acervo objetos da sua cultura material e espiritual: perscrutam as salas de exposições, desorganizam os arquivos, identificam e se veem em cada adereço, cocar, bracelete e adorno em exposição. Estão decididos a levar "tudo de volta!" para "desespero" da equipe de filmagem e apreensão das irmãs da congregação ("proprietária" da cultura Tariana usurpada no tempo das missões). Assim, em sequências como essa, não conseguimos identificar se a luta de Vincent acontece no cinema em direção à realidade ou no território da realidade através do cinema. Decorrente do seu envolvimento com o mundo histórico diante da câmera, inevitavelmente, é um cineasta que pertence ao campo e ao fora de campo da imagem, mesmo quando não há qualquer sinal físico em cena.

43. Os Tariana integram a família linguística Aruak, habitam o Amazonas e a Colômbia e compreendem, respectivamente, uma população de 2.684 (Siasi/Sesai, 2014) e 205 (1998) indivíduos. A história do contato é marcada, no início do século 20, pelas missões salesianas (Povos Indígenas do Brasil / Instituto Socioambiental-IS A, 2018). 


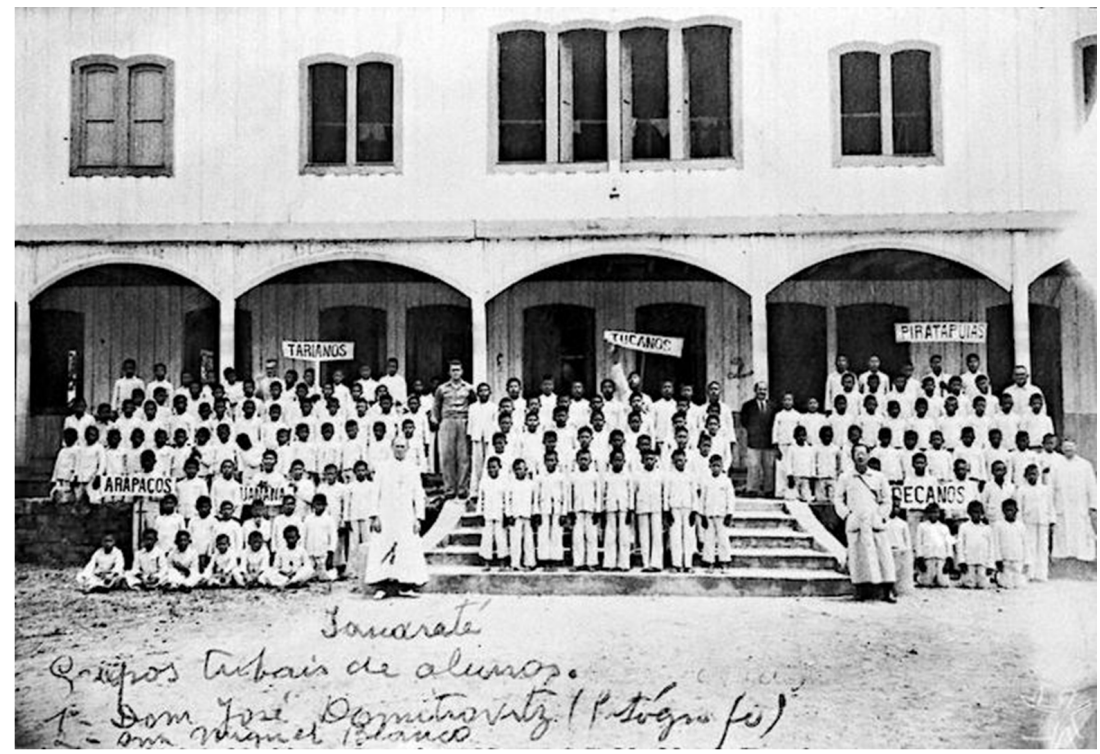

Figura 5. Missões Salesianas em Iauaretê I ( A Arquivo da Diocese de São Gabriel da Cachoeira - AM

No âmbito dos cineastas indígenas, o embate dos povos originários com as missões católicas, no que se revela sobre um certo desejo de colonização cultural, aparece fortemente em Tsõ'Rehipãr - Sangradouro (2009), de Divino Tserewahú, Tiago Campos Torres e Amandine Goisbault, e no já citado Pi'õnhitsi, mulheres xavante sem nome. Nesses filmes, as interferências salesianas nos rituais sagrados Xavante entram em cena, especialmente, em Tsõ'Rehipãr Sangradouro, com as estruturas físicas da Missão Salesiana, recorrentemente, no plano de fundo como dimensão colonial permanente, como escreveriam os decolonialistas (Mignolo, 2017; Quijano, 2005). Em Kene Yuxi - As voltas do kene (2010), de Zezinho Yube, com as sequências do culto na igreja da aldeia e do depoimento de um indígena que afirma a prevalência de Jesus sobre os rituais nativos, a presença evangélica entre os Huni Kuin ${ }^{44}$ é filmada com a desolação de uma perda irreparável. Nos filmes do Coletivo Guarani Mbya, essa questão ganha relevo, com a recorrência no espaço fílmico das ruínas jesuíticas de São Miguel das Missões-RS, ou melhor, da reutilização das ima-

44. Os Huni Kuin (que também é a sua autodenominação), pertencem a família linguística Pano, habitam territórios do Acre-AC e do Peru, compreendem uma população com cerca de 13 mil indivíduos (Siasi/Sesai, 2014; INEI, 2007). A denominação colonial é Kaxinawá ("morcego" ou "gente com hábito de andar à noite) (Povos Indígenas do Brasil / Instituto Socioambiental-ISA, 2018). 
gens do espaço histórico como espaço cenográfico e como forma de inscrição da colonização espiritual sobre os Guarani. Em Tava, a casa de pedra (2012), essa presença é mais concreta e, portanto, acontece em outra geografia diferente da mato-grossense Xavante, o que só demonstra, nas lentes dos cineastas indígenas do VNA, que a colonialidade cultural não é fenômeno localizado. É, outrossim, uma dominante geográfica factual transfigurante do mundo histórico indígena - do Norte ao Sul do Brasil ${ }^{45}$, como transfigurante foi a política jesuítica que vemos, recorrentemente, na filmografia dos Guarani Mbya, a partir, por exemplo, das lentes coloniais de A Missão (1986), de Rolland Joffé, que são colocadas em crise.

São aspectos que seguem um diapasão de autorreferencialidade que, em diversos níveis (espaço histórico que se transmuta em espaço fílmico), também marca A festa da moça e A morada de Hakowo, último trabalho de Vincent Carelli até o momento em que escrevo estas linhas. Nesse âmbito, a autorreferencialidade, própria do modo reflexivo que desnuda a construção narrativa (Nichols, 2005; Penafria, 1999), do início ao fim do fazer documentário, não esconde o processo de feitura de um filme. Mas, ao contrário, tende a revelálo ainda que regulando o que mostra e o que ausenta. Em uma análise de A festa da moça, observa-se que o filme já começa com as interrupções de imagens, que são congeladas pela montagem antes que ganhem uma forma, e que as fragmentam, antes que os planos se alonguem em planos-sequências, o que inscreveria, em quadro, uma sensação maior de temporalidade... e de realidade. Em seu primeiro documentário, Vincent dá sinais das mediações fílmicas em processo, com passagens autorreferenciais se sucedendo de ponta a ponta: o visionamento dos rituais no monitor de TV; o jogo entre os materiais brutos e finalizados; as (re)encenações das manifestações culturais; e as informações dadas pelo narrador em off de que "Este vídeo é o encontro dos Nambikwara com a sua imagem" e que, a partir de determinado momento, passou a ser "dirigido" pelo Capitão Pedro Maimãndê - líder Nambikwara.

Já no caso dos cineastas e coletivos indígenas, as instâncias "produtor processo - produto" (Penafria, 1999: 69), em quadro, não são acidentais: ora integram o corpo narrativo e com ele se confundem (Pi'ónhitsi, mulheres xavante sem nome), ora testemunham a própria condição histórica dos diretores

45. A contundência do registro sobre a colonialidade nos filmes do VNA contrasta com a abordagem do cineasta então tenente Luiz Thomaz Reis da Comissão Rondon. Incialmente, prevaleceu a imagem do índio tribal para depois dar lugar à imagem do índio integrado/civilizado: "No filme Rituaes e festas Bororo (1917) houve a supressão da presença salesiana e de elementos aculturados" (Tacca, 2004: 350). Mesmo quando a aculturação entra em cena, em Inspectorias de fronteira - rio Negro (1938), o que se vê são sequências de "reiteração e reafirmação na exaltação da ação salesiana" (Tacca, 2004: 353). 
nativos, ao filmarem o seu mundo e a si sempre nesse mundo com a câmera na mão, tornando, assim, indissociáveis o que está no campo e no fora de campo da imagem (Desterro Guarani). Como pode ser constatado, é no cinema autorreferencial de Vincent Carelli que o Outro ganha espaço no processo de feitura documental, seja quando refletido ou refratado pela câmera, seja quando se posiciona no outro lado do espelho e "dirige-o" - ou tenta dirigi-lo. Em uma das últimas parcerias entre Vincent e o cineasta Ashaninka Wewito Piyãko (A morada de Hakowo), a autorreferencialidade coloca em crise a relação da mise en scène com a auto-mise en scène, ao instalar um campo de força entre a direção e o personagem que tenta, o tempo todo, dirigir(-se) a cena, o que, consequentemente, desestabiliza as instâncias clássicas de poder do documentário. Porém, não obstante a centralidade em quadro do velho Ashaninka Hakowo, a sua condição - entre sujeito e objeto - é relativizada pelo corte final, uma vez que, em suma, as decisões são tomadas pelos diretores e não pelo Outro, ou melhor, por quem é filmado, pois o Outro (Wewito) aqui também pertence ao antecampo, é instância produtora; dá as regras sobre o que pode ou não figurar em quadro; e, com Vincent (o olhar não indígena da direção, a outra instância de poder no processo de feitura de planos, quadros, cenas ...), desnuda o velho Ashaninka que, com a sua auto-mise en scène, tenta em vão controlar a câmera que o captura.

Atravessando quatro décadas no cinema documentário, além de dirigir quase 50\% dos filmes, Vincent Carelli participou de, praticamente, todas as produções do Vídeo nas Aldeias, como produtor, roteirista, diretor de fotografia, câmera, editor etc. Essas produções, esteticamente, variam do cinema (Iauaretê - cachoeira das onças) à televisão (Antropofagia Visual), de um tom mais participativo (Corumbiara), passando por modelos mais convencionais (Yaõkwa), a vídeos de apresentação quase reportagens (Cineastas Indígenas, 2010). Do encontro com o mundo indígena, paisagens múltiplas foram sendo registradas e confrontadas. Das abordagens sobre etnias (Pemp - sobre os Gavião Parkatêjê; e $O$ Espírito da $T V$ - sobre os Wajãpi) à caracterização de personagens (Krohokrenhum - Eu não posso morrer de graça - sobre o Capitão Krohokrenhum), o painel é amplo e labiríntico. Também compartilhou a direção com os companheiros de luta, como em Ninguém come carvão (1991 - com Murilo Santos), A arca dos Zo'é (com Dominique Gallois), De volta à terra boa (com Mari Corrêa) e Yaõkwa (com Fausto Campoli).

Enquanto, nesse caso, a autorreferencialidade revela as possibilidades e impossibilidades do domínio com o/pelo Outro, também, sob a câmera de Vincent Carelli e dos cineastas indígenas, quando o filme dobra-se sobre si mesmo, revela-se um cinema de partilha e colaboração. Em um jogo ótico emblemá- 
tico desse gesto, no qual as autorias confluem, intercalam-se e se confundem, a montagem de Jane Moraita, nossas festas (1995) amalgama Vincent e Kasipirinã Wajãpi em um só e mesmo corpo material narrativo, quando os alterna no espaço fílmico. Então, vemos Kasipirinã (o diretor do filme) com a câmera a filmar a urbanidade de São Paulo dos anos 1990 para, de repente, entrar em quadro Vincent, com a sua câmera registrar o cineasta Wajãpi em atividade. Vincent aparece com a câmera no primeiro filme do VNA dirigido por um cineasta indígena (o que não deixa de ser sintomático sobre os limites de um cinema indígena, digamos assim, autônomo), no qual Kasipirinã registra as tradições do seu povo e as comenta, a partir de um monitor de TV posicionado logo atrás do seu corpo como se estivesse em um making off de um filme que realizara, mas que, na verdade, é o próprio filme que o tem como apresentador/diretor/personagem ocupando todas as centralidades da materialidade narrativa mesmo em uma situação em que, inicialmente, parece ser personagem diante das lentes de um terceiro que o registra.

\section{Considerações finais}

O Vídeo nas Aldeias abre uma infinidade de campos de investigação para os estudos de cinema e, mais especificamente, do documentário. Em qual moldura teórica, histórica e cinematográfica pode ser situada a experiência do VNA - especialmente a escritura documental de Vincent Carelli? Parece-nos que, por mais que haja uma descentralização da produção cinematográfica e tenha sido aberto espaço para os povos subalternos, excluídos e marginalizados, o Terceiro Cinema ou o cinema periférico não podem se apresentar como molduras, como já havíamos assinalado, pois o mundo que se apresenta pela/na câmera dos cineastas indígenas e não indígenas não coadunam com o olhar de fora, que usa e embala o Outro (Prysthon, 2006) ${ }^{46}$. Ademais, ao situarmos no esquadro da mídia indígena clássica, exala um incômodo "gueto midiático" e a exclusão de um espaço compartilhado com outros agentes/parceiros.

As problemáticas que surgem, à medida que percorremos a obra de Vincent Carelli e dos cineastas e coletivos indígenas, precisam ser aprofundadas e materializadas a partir de análises fílmicas e contextuais. Primeiramente, sem a idealização do Outro (ele mesmo muitas vezes produtor de estereótipos e um sujeito histórico, igualmente, com todas as suas contradições); segundo, considerando os limites do que comumente chamamos de constituição do sujeito no âmbito da mídia indígena, pois, como assinalamos, já se tornou lugar comum a atribuição apenas pelo fato de carregarem a câmera sobre o ombro; e, terceiro,

46. Em desacordo com Salazar (2004) que pensa na mídia indígena em termos de "atualização" do Terceiro Cinema. 
sem as posições maniqueístas que só conseguem resolver o problema se a solução estiver em um dos campos do esquadro. Talvez, a questão mais central do VNA seja o lugar que o Outro ocupa no texto e no contexto dos filmes, no comando da mise em scène ou da auto-mise scène.

Como nos relacionamos com as imagens, qual a responsabilidade do olhar produzido sobre, com, para e pelo Outro e qual a nossa responsabilidade sobre o que vemos? Depois de um percurso por sua obra, em diálogo com as cinematografias indígenas, ver com Vincent Carelli é descobrir redes de imagens inacabadas ou proto-finalizadas. Percorrer os fios tecidos pelos seus filmes, que se completam em outros e formam um complexo orgânico, a partir dos filmes que foram realizados por outros cineastas vinculados ao VNA, com e pelo Outro, observa-se sobretudo não uma autorreferencialidade sobre o meio ou sobre um construtor imagético precedente, mas uma lógica de reutilização de imagens que não desaparecem entre materiais brutos e finalizados. No cinema de Vincent Carelli, em nenhum momento, as imagens se perdem, são arquivadas ou deixadas para trás. Aponta, ao contrário, para um veio documentário não aleatório, mas processual e sistêmico decorrente de um fazer documentário, de um processo de criar o mundo em imagens em permanência.

A partir de A festa da moça, testemunhamos que cada filme dá origem a mundos que se assemelham ao mundo histórico. Imagens que eram apenas começos, inícios, princípios - da luta que Vincent trava "no", "com", "por dentro" e "a partir" do cinema documental sob o risco do real, que o atravessa, transpassa-o, transporta-o, ultrapassa-o e o funda (Comolli, 2008: 170). Em Uma escola Hunikuin (2008), dirigido em parceria com Zezinho Yube, Ernesto de Carvalho e Mari Corrêa, dirigido com e sobre o Outro sobre as suas formas de vida, dois modelos de aprendizagem, simbolicamente, entram em confronto. Em um dos últimos planos, o velho Huni Kuin adentra o espaço da escola e convida o menino para ver o ritual do seu povo que acontecia no terreiro da aldeia que víamos de dentro da sala de aula enquanto os alunos faziam as atividades. É o mesmo menino Huni Kuin que não saiu para participar do ritual, quando o professor a turma para vivenciar suas tradições transcorrendo fora do "espaço institucionalizado de educação". Qual o lugar de formação Huni Kuin? O que e como se deve aprender?

Nesse gesto, a questão indígena mais uma vez se inscreve em quadro e é como se todo o cinema de Vincent e a história dos povos originários coubessem nesse curta-metragem. Portanto, se pudéssemos escolher um traço que atravessa, em maior ou menor extensão, "todos" os filmes de Vincent Carelli, elegeríamos a questão indígena, que enfim se confunde - entre a expropriação e a resistência seculares - com a problemática do patrimônio histórico e 
territorial dos povos originários, permanentemente, ameaçado. Como veio da sua escritura fílmica, a questão indígena, que já estava no primeiro filme do VNA e de Vincent (A festa da moça), configura-se problemática central desde o prólogo de Martírio, a partir de arquivos que apresentam os discursos do telejornalismo e de parlamentares brasileiros sobre o "índio" como entrave para o agronegócio, a produção e o crescimento do país. Como contranarrativa, as lentes pós-coloniais de Vincent Carelli erguem outras visões sobre os povos originários distantes das que, comumente, transformam o "índio em uma ficção" (Carelli, 2011), pois sabemos com Jean-Louis Comolli (2008: 30) que "Não se filma nem se vê impunemente".

$\mathrm{Se}$, com a crítica decolonial, sabemos que a colonialidade, de forma objetiva e subjetiva, perpassa esse cenário, com Adolfo Colombres (1985, p. 37) já ficou claro que o olhar de fora (do cineasta não indígena ou etnográfico), ao adentrar o mundo dos povos originários, não entra em um "campo indílico de rosas", mas, inevitavelmente, uma "situação colonial estabelecida". Por isso, como pertence a outros valores e a outra história, as implicações podem ser várias, como uma abordagem etnocêntrica do Outro baseada em estereótipos, simplificada e reduzida ao estritamente cultural - caso não valorize as especificidades constitutivas da história e da cultura de povo, a historicidade e a consciência da sua condição atual, e, sobretudo, não promova um processo de autogestão que permita a passagem da representação a autorrepresentação (Colombres, 1985) ou na abra espaço para as demandas e a auto-mise en scène do Outro.

Perscrutar a zona intermediária - entre o objeto e a teoria (Prysthon, 2016) - é fundamental para se chegar à justa medida entre forma e contexto e, consequentemente, a poética imperfeita para além das molduras prévias: Terceiro Cinema, Cinema Periférico, Filme Etnográfico e Mídia Indígena. Considerando o que se desenhou no centro e, ao mesmo tempo, no entorno do VNA, ao longo dos últimos 30 anos, como produtora audiovisual e escola de formação de cineastas indígenas, tomamos o primeiro filme de Vincent Carelli - A festa da moça - com vistas à problematização das dimensões fílmicas, históricas e políticas de uma escritura documental particular, mas em rede e sintonizada. Nas linhas anteriores, descobrimos os registros e as (re)invenções dos/nos seus filmes, que se irradiaram, refletiram e costuraram contextos mais amplos do que as suas próprias tapeçarias. Diante da complexidade do mundo histórico fílmico, que se descortinou em nosso percurso e tentamos apreender com a atenção e o rigor necessários, aplico a poética documental de Vincent Carelli as palavras que Lévi-Strauss (1996: 40) aplicou ao mundo histórico indígena 
que encontrou na década de 1930 quando desbravou os tristes trópicos: "Tudo o que percebo me fere, e reprovo-me em permanência não olhar o suficiente".

\section{Referências}

Alvarenga, C. (2017). Da cena do contato ao inacabamento da história: Os últimos isolados (1967-1999), Corumbiara (1986-2009) e Os Arara (1980-). Salvador: EDUFBA.

Araújo, J. J. de (2012). A realização de documentários por comunidades indígenas: notas sobre o projeto Vídeo nas Aldeias. Intexto, 26: 151-16. Porto Alegre.

Araújo, J. J. de (2015). Cineastas indígenas, documentário e autoetnografia: um estudo do projeto vídeo nas aldeias. São Paulo: Tese de Doutorado, Unicamp.

Aumont, J. (1995). Meu caríssimo objeto. Imagens, 5: 18-27. Campinas/sP.

Bernardet, J.-C. (2003). Cineastas e imagens do povo. São Paulo: Companhia das Letras.

Carelli, V. (2011). Um novo olhar, uma nova imagem. In A. C. Z. Araújo (org.), Vídeo nas Aldeias 25 anos (1986-2011) (pp. 42-51), Olinda: Vídeo nas Aldeias.

Caixeta de Queiroz, R. (2008). Cineastas indígenas e pensamento selvagem. Devires - cinema e humanidades, 5(2): 98-125. Belo Horizonte.

Colombres, A. (org.) (1985). Cine, antropología y colonialismo. Buenos Aires: Ediciones del Sol / CLACSO.

Comolli, J.-L. (2008). Ver e poder. Belo Horizonte: Editora UFMG.

Cesar, A. (2012). Tradição (re)encenada: o documentário e o chamado da diferença. Devires - cinema e humanidades, 9(1): 86-97. Belo Horizonte.

Cesar, A.; Brasil, A.; Leandro, A. \& Mesquista, C. (2017). Nomear o genocídio: uma conversa sobre Martírio, com Vincent Carelli. Revista Eco Pós, 20(2): 232-257. Rio de Janeiro.

CINUSP P E. (2018). Debate I Martírio: Vincent Carelli, Tatiana Almeida e Esther Hamburguer. Disponível em: www.youtube.com/watch?v=1gZ7A gZ8liE

Córdova, A. (2011). Estéticas enraizadas: aproximaciones ao video indígena al América Latina. Comunicación y médios, (4): 81-107. Chile. 
Felipe, M. A. (2018a). Aportes para análise fílmica em contextos educativos: o cinema de Aloysio Raulino (1968-1980). In. C. A. Noronha, T. M. N. Barbosa \& M. F. F. Araújo (org.), Leitura e escrita em diferentes contextos de aprendizagem: letramentos, sustentabilidade e perspectiva de ensino (pp. 259-287), São Paulo: Editora Livraria da Física.

Felipe, M. A. (2018b). Escrituras fílmicas problematizadoras do mundo histórico: a "questão indígena" no Brasil. Famecos - mídia, cultura e tecnologia, 25(2): 1-30, mai./ago. DOI: http://dx.doi.org/10.15448/19803729.2018.2.29351

France, C. de. (1998). Cinema e antropologia. Campinas, SP: Editora Unicamp.

France, C. de. (2000). Antropologia fílmica: uma gênese difícil, mas promissora. In C. de France (org.). Do filme etnográfico à antropologia fílmica (pp. 13-42). Campinas, SP: Editora da Unicamp.

Freire, M. (2011). Documentário: ética, estética e formas de representação. São Paulo: Annablume.

Freire, M. \& Lourdou, P. (2009). Introdução. In M. Freire \& P. Lourdou (orgs.), Descrever o visível: cinema documentário e antropologia filmica (pp. 9-22). São Paulo: Estação Liberdade.

Frota, M. (2018). Taking Aim e a Aldeia Global. Disponível em: www.mnem ocine.com.br/osbrasisindigenas/frota.htm

Gallois, D. \& Carelli, V. (1995). "Vídeo nas Aldeias": a experiência Waiãpi. Cadernos de Campo, 2(2): 25-36. São Paulo.

Gallois, D.; Carelli, V. (1995). Vídeo e diálogo cultural: experiência do projeto Vídeo nas Aldeias. Horizontes antropológicos, 1(2): 61-72. Porto Alegre.

Ginsburg, F. (2011). Vídeo parentesco: um ensaio sobre A Arca dos Zo'é e Eu já fui seu irmão. In A. C. Z. Araújo (org.), Vídeo nas Aldeias 25 anos (1986-2011) (pp. 172-179). Olinda: Vídeo nas Aldeias.

Guimarães, C. (2012). Atração e espera: notas sobre os fragmentos não montados de Os Arara. Devires - cinema e humanidades, 9(2): 50-69. Belo Horizonte.

Gonçalves, M. A. (2016). Intrépidas imagens: cinema e cosmologia entre os navajo. Sociologia e antropologia, 6(03): 635-667, dez. Rio de Janeiro.

Lévi-Strauss, C. (1996). Tristes Trópicos. São Paulo: Companhia das Letras.

Moraes, F. (2017). A Luta do Cinema Indígena... Zum: revista de fotografia, (12): 76-95. São Paulo. 
Nichols, B. (2005). Introdução ao documentário. Campinas, SP: Papirus.

Oliveira, L. de (2018). Na aldeia, na mídia, na rua: reflexões sobre a resistência Kaiowá e Guarani em diálogo com o contexto de golpe político no Brasil e com o campo hegemônico da comunicação. Mídia e cotidiano, abr., 12(1): 109-131. Niterói, RJ.

Penafria, M. (1999). O filme documentário: história, identidade, tecnologia. Lisboa: Edições Cosmos.

Penafria, M. (2009). Análise de Filmes - conceitos e metodologia(s). BOCC Biblioteca On-line de Ciências de Comunicação.Disponível em: www.bo cc.ubi.pt/pag/bocc-penafria-analise.pdf.

Povos Indígenas do Brasil / Instituto Sócioambiental-ISA. Disponível em: https://pib.socioambiental.org/pt/P\%C3\%A1gina_principal

Prysthon, A. (2006). Imagens periféricas: os estudos culturais e o terceiro cinema. E-Compós, 10(10): 1-15. São Paulo.

Prysthon, A. (2016). Stuart Hall, os estudos fílmicos e o cinema. Matrizes, 10(3): 77-88. São Paulo.

Quijano, A. (2005). Colonialidade do poder, eurocentrismo e América Latina. In E. Lander (org.), A colonialidade do saber: eurocentrismo e ciências sociais - perspectivas latino-americanas (pp. 107-130). Buenos Aires: CLACSO.

Ramos, F. P. (2005). A cicatriz da tomada: documentário, ética e imagem intensa. In F. P. Ramos (org.), Teoria contemporânea do cinema: documentário e narratividade ficcional (pp. 159-226). São Paulo: Senac São Paulo.

Rahe, N. (2018). Cria dos índios. Disponível em: www.livrariacultura.com.br/ revistadacultura/reportagens/cria-dos-indios

Rede Amazônica. (2016). Acre TV: cineasta produz série 'Nokun Txai - Nossos Txais' no estado. Disponível em: http://redeglobo.globo.com/redeam azonica/acre/noticia/2016/06/acre-tv-cineasta-produz-serie-nokun-txai-n ossos-txais-no-estado.html

Salazar, J. F. (2004). Imperfect media: the poetics indigenous media in chile. Thesis in Doctor of Philosophy Communication and Media, University of Western, Sidney.

Salazar, J. F. \& Córdova, A. (2008). Imperfect media and poetics of indigenous video in Latin America. In Pamela Wilson e Michelle Stewart. Global indigenous media: cultures, poetics, and politics (pp. 39-57). Durham and London: Duke Univerty Press. 
Schefer, R. (2016). Mueda, Memória e Massacre, de Ruy Guerra, o projeto cinematográfico moçambicano e as formas culturais do Planalto de Mueda. Comunicação e Sociedade, 29: 27-51. Portugal.

Shohat, E. \& Stam, R. (2006). Crítica da imagem eurocêntrica. São Paulo: Cosac Naify.

Shohat, E. \& Stam, R. (2005). Teoria do cinema e espectatorialidade na era dos "pós". In F. P. Ramos (org.), Teoria contemporânea do cinema: pósestruturalismo e filosofia analítica (pp. 393-424). São Paulo: Senac São Paulo.

Stam, R. (2008). Multiculturalismo tropical. São Paulo/SP: Edusp.

Tacca, F. de. (2004). Luiz Thomaz Reis: etnografias fílmicas estratégicas. In F. E. Teixeira (org.), Documentário no Brasil (pp. 313-370), São Paulo: Summus.

Vanoye, F. \& Goliot-Lété, A. (1994). Ensaio sobre análise fílmica. Campinas: Papirus.

Wikipédia (2018). Vincent Carelli (Verbete). Disponível em: https://pt.wikipe dia.org/wiki/Vincent_Carelli

\section{Filmografia}

A arca dos Zo'é (1993), de Vincent Carelli.

A família de Elizabeth Teixeira (2013), de Eduardo Coutinho.

A festa da moça (1987), de Vincent Carelli.

A história de Akykysia, o dono da caça (1998), de Dominique Gallois.

A morada de Hakowo (2017), de Vincent Carelli e Wewito Piyãko.

Antropofagia Visual (1995), de Vincent Carelli.

As voltas do kene (2010), de Zezinho Yube.

Boca livre no Sararé (1992), de Vincent Carelli.

Cineastas indígenas (2010), de Vincent Carelli.

Cabra marcado para morrer (1984), de Eduardo Coutinho.

Corumbiara (2009), de Vincent Carelli.

Desterro Guarani (2011), de Vincent Carelli, Ariel Ortega, Patrícia Ferreira e Ernesto de Carvalho

De volta à terra boa (2008), de Vincent Carelli e Mari Corrêa.

Eu já fui seu irmão (1993), de Vincent Carelli. 
Filmando Manã Bai (2008), de Vincent Carelli.

Iauaretê - Cachoeira das onças (2006), de Vincent Carelli.

Índio na Têvê (2000), de Vincent Carelli.

Itão Kuegu: as hipermulheres (2011), de Takuma Kuikuro, Carlos Fausto e Leonardo Sette.

Kiarãsâ Yõ Sâty - O amendoim da cutia (2005), de Komoi Panará e Paturi Panará.

Krôhôkrenhum - Eu não posso morrer de graça (2011), de Vincent Carelli e Ernesto de Carvalho.

Martírio (2016), de Vincent Carelli.

Meu amigo garimpeiro (1994), de Dominique Gallois.

Mokoi Tekoá, Petei Jeguatá - Duas aldeias, uma caminhada (2008), de Ariel Ortega, Germano Benito e Jorge Morinico.

Morayngava (1997), de Virgínia Valadão e Regina Muller.

Nanook, o esquimó (1922), de Robert Flaherty

Ninguém come carvão (1991), de Vincent Carelli e Murilo Santos.

Nós e a cidade (2009), de Ariel Ortega, Germano Benito e Jorge Morinico.

O espírito da TV (1990), de Vincent Carelli.

Para os nossos netos (2008), de Vincent Carelli e Mari Corrêa.

Peixe Pequeno (2010), de Vincent Carelli e Altair Paixão.

Pemp (1988), de Vincent Carelli e Murilo Santos.

Pi'õnhitsi, mulheres xavante sem nome (2009), de Divino Tserewahú.

Placa não fala (1996), de Vincent Carelli e Dominique Gallois.

Priara Jô - Depois do ovo, a guerra (2008), de Komoi Panará.

Primárias (1960), de Robert Drew.

Qual é o jeito Zé? (1990), de Vincent Carelli.

Segredos da mata (1998), de Vincent Carelli e Dominique Gallois.

Tava, a casa de pedra (2012), de Vincent Carelli, Ariel Ortega, Patrícia Ferreira e Ernesto de Carvalho.

Terra dos Índios (1979), de Zelito Viana.

Tsõ'Rehipãr - Sangradouro (2009), de Divino Tserewahú, Tiago Campos Torres e Amandine Goisbault.

Uma escola Hunikuin (2008), de Vincent Carelli, Zezinho Yube e Mari Corrêa. 
Vídeo nas Aldeias (1989), de Vincent Carelli.

Wai'a - O segredo dos homens (1987), de Virgínia Valadão.

Wai'á Rini, o poder do sonho (2001), de Divino Tserewahú.

Wapté Mnhõnõ - Iniciação do jovem xavante (1998), de Divino Tserewahú.

Yãkwa, Banquete dos Espíritos (1995), de Virgínia Valadão.

Yaõkwa - Um patrimônio ameaçado (2009), de Vincent Carelli e Fausto Campoli. 